\title{
AFH-C.00007
}

CA-168-RAD- 5

\section{TRANSMISSIVITY AND HYDRAULIC CONDUCTIVITY OF SATURATED SEDIMENTARY ROCKS IN THE \\ HANFORD RESERVATION}

\author{
By \\ Dr. Raul A. Deju \\ Consultant and Project Director \\ Atlantic Richfield Hanford Company \\ Richland, Washington \\ and \\ W. K. Summers \\ consultant \\ Atlantic Richfield Hanford Company \\ Richland, Washington
}

April 1, 1975

This report is based on work sponsored by the Atlantic Richfield Hanford Company under United States Energy Research and Development Administration Contract AT $(45-1)-2130$ 


\section{DISCLAIMER}

This report was prepared as an account of work sponsored by an agency of the United States Government. Neither the United States Government nor any agency Thereof, nor any of their employees, makes any warranty, express or implied, or assumes any legal liability or responsibility for the accuracy, completeness, or usefulness of any information, apparatus, product, or process disclosed, or represents that its use would not infringe privately owned rights. Reference herein to any specific commercial product, process, or service by trade name, trademark, manufacturer, or otherwise does not necessarily constitute or imply its endorsement, recommendation, or favoring by the United States Government or any agency thereof. The views and opinions of authors expressed herein do not necessarily state or reflect those of the United States Government or any agency thereof. 


\section{DISCLAIMER}

Portions of this document may be illegible in electronic image products. Images are produced from the best available original document. 


\section{TRANSMISSIVITY AND HYDRAULIC CONDUCTIVITY OF SATURATED SEDIMENTARY ROCKS IN THE HANFORD RESERVATION}

\section{INTRODUCTION}

The Hanford Reservation (Figure 1) occupies 365,000 acres (570 square miles) of land within the Columbia Basin geologic province. This location was selected in early 1943 by the U. S. Army Corps of Engineers as the site for reactor and chemical separation facilities for the production and purification of plutonium needed in the development of nuclear weapons. [ $\left.{ }^{1}\right]$ The Reservation is divided into the $100,200,300,400,600,700,1100$, and 3000 Areas.

Eight graphite-moderated reactors using Columbia River water for once-through cooling and one reactor ( $N$ Reactor) using a recirculating water coolant were built along the Columbia River. Only the $\mathrm{N}$ Reactor is presently operating. It is being used to produce both plutonium and electricity. The reactors are located in the 100 Areas (Figure 1).

The 200 Areas (Figure 1) include all reactor fuel reprocessing and waste management facilities. The 200 West and 200 East Areas are located on a plateau south of Gable Butte and Gable Mountain and about 7 miles from the Columbia River. These facilities include "tank farms" where wastes containing high-level concentrations of radionuclides are currently stored. The tank farms include:

- One hundred forty-nine underground tanks ranging in capacity from 50,000 to $1,000,000$ gallons.

- Three double-walled 1,000,000-galion underground tanks. 

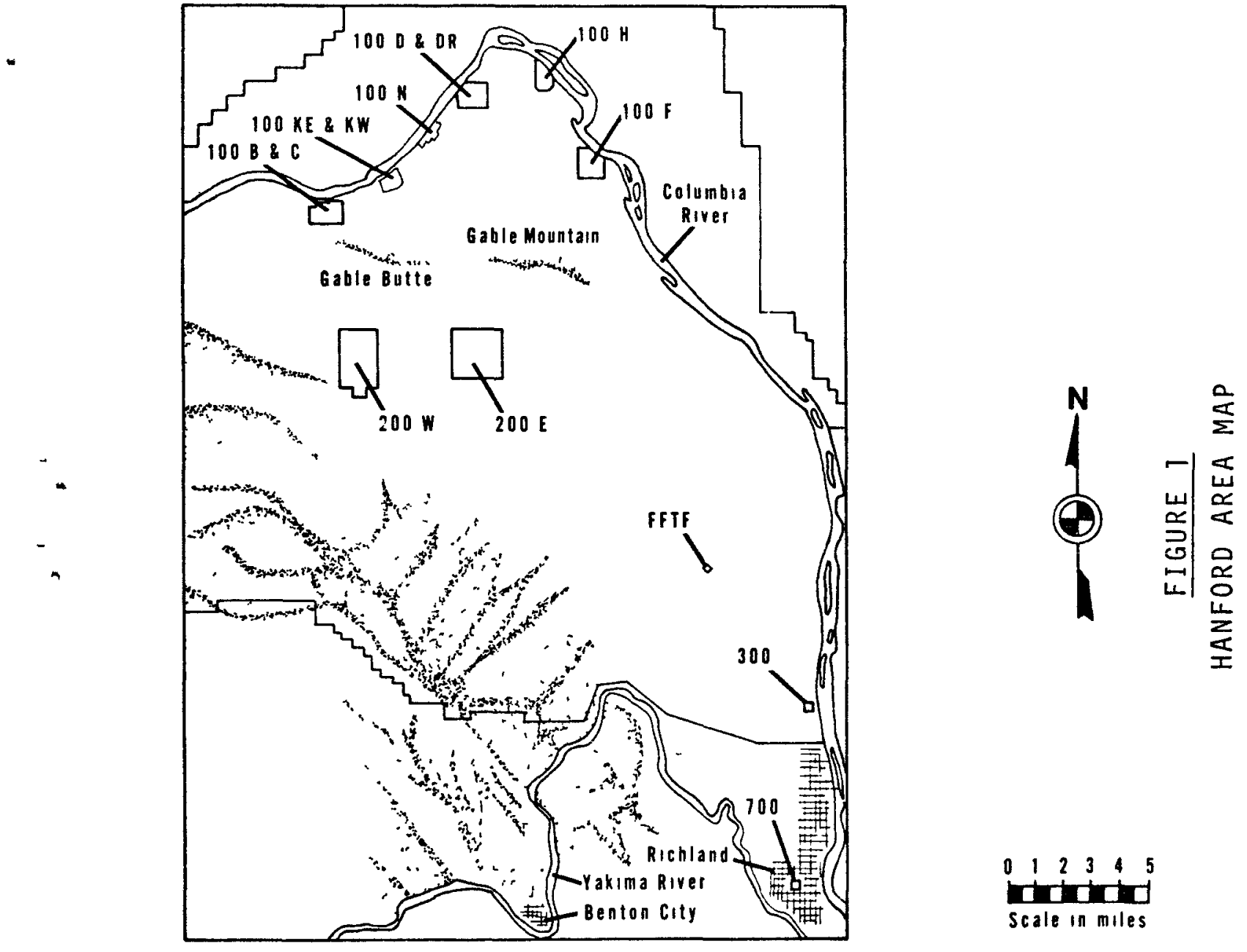
- Four double-walled 1,000,000-gallon underground tanks presently under construction.

In addition to the tank farms, the 200 Areas include:

- Four water evaporators used to convert radioactive waste into a less mobile sludge (two currently in service).

- One hundred seventy-seven cribs that have been used for the disposal of intermediate-level liquid waste.

- Ponds and ditches (covering under 400 acres) for the disposal of low-level wastes.

More than 5 million cubic feet of contaminated dry solid wastes (used equipment, paper, construction debris) are buried at Hanford in special burial trenches within and outside the 200 Areas.

The 300 Area is located just north of the city of Richland (Figure 1 ) and includes both the reactor fuel manufacturing facilities and the research and development laboratories.

The 400 Area is located seven miles northwest of the 300 Area and includes the Fast Flux Test Facility (FFTF) presently under construction.

The 600 Area includes all the remaining land within the Hanford Reservation. It serves as a buffer between the facility at Hanford and the nearby communities.

The 700 Area includes administration offices. The 1100 Area includes central stores and the bus and rail operational center for the Project. The 3000 Area includes private laboratories and Port of Benton land areas.

To adequately understand the groundwater flow regime of the Hanford Reservation, data have been gathered and tests 


\section{TABLE I}

DRILLER LOG OF WELL 399-5-2

\begin{tabular}{rr} 
Depth, & Feet \\
\hline From & To \\
\cline { 2 - 2 } 4 & 3 \\
8 & 7 \\
16 & 15 \\
33 & 32 \\
35 & 34 \\
49 & 48 \\
66 & 65 \\
68 & 67 \\
70 & 69 \\
81 & 80 \\
90 & 99 \\
100 & 105 \\
106 & 120 \\
121 & \\
122 & 140 \\
141 & 154 \\
155 & 160 \\
161 & 176 \\
177 & 192 \\
193 & 194 \\
195 & 205 \\
206 & 208 \\
209 & 230 \\
231 & 235 \\
236 & 274 \\
275 & 279 \\
280 & 300 \\
301 & 305 \\
306 & 310 \\
311 & 315 \\
315 & 319 \\
320 & 324 \\
325 & 334 \\
335 & 344 \\
345 & 346 \\
347 & 359 \\
360 & 369 \\
370 & 379 \\
380 & 399 \\
400 & 406 \\
407 & 409 \\
410 & 419 \\
420 & 423 \\
424 & \\
&
\end{tabular}

Material Penetrated

Topsoil, boulders, sand, gravel

Boulders, sand, gravel, silt

Sand, gravel, silt

Sand, gravel

Sand, gravel, little silt

White sand, gravel

White sand, clay, gravel

Clay, gravel

Clay

Blue, brown, and yellow clay

clay, gravel, coarse sand

Black sand, little gravel

Black sand, gravel

Sand, gravel, wood

Sand, gravel, clay

Sand, gravel, boulders

sand, basalt, clay

Sand, gravel, clay

Clay

Clay, coarse sand

Clay, black sand, basalt

Sand, basalt

Basalt

Basalt, volcanic mud

Porous basalt, gravel

Hard basalt

Greenish-blue silt, sand

Bluish-greenish shale, sand

Green silt

Black mud

Porous basalt

Basalt

Shale, basalt

Basalt, shale, quartz

Basalt, green shale

Basalt, blue shale

Hard basalt

Porous basalt

Hard basalt

Hard, gray basalt

Black basalt

Hard basalt

Basalt

Hard basalt

Solid basalt--total depth 
TABLE I I

GEOLOGICAL LOG OF WELL 399-5-2

Alluvium:

Sand, silty; about $40 \%$ quartz and $60 \%$ basalt; $\frac{\text { Thickness }}{\text { Feet }} \quad \frac{\text { Depth }}{\text { Feet }}$

angular-to-subangular; poorly sorted--mostly

coarse-to-fine sand with some $1 / 4$ " to $1 / 2$ "

diameter gravel and a few boulders; some

artificial fill in places.

Glaciofluviatile and Fluviatile Deposits:

Gravel, sandy and bouldery; contains a small

small amount of silt; basalt predominates in the gravel and coarse sand and makes up $80 \%$ of the finer sand; sand is angular-to-subangular, and gravel is rounded-to-subrounded.

Gravel, sandy and slightly silty; pebbles, averaging $1 "$ to 3 " in diameter, are subrounded-to-subangular, about $40 \%$ basalt and $60 \%$ exotic types; material is about $40 \%$ gravel, $55 \%$ medium-to-very fine sand, and $15 \%$ silt.

Gravel, sandy; gravel forms $60 \%$ of sample, sand 25\%, and silt 15\%; ratio of basalt-toexotic types in gravel is about 658:35\%; sand is about $55 \%$ basalt and $45 \%$ exotics and quartz; gravel is subangular-to-subrounded and has 3" maximum diameter and 1 " average diameter.

Gravel, coarse-to-fine, and coarse sand; maximum diameter of gravel 4", average diameter 2"; pebbles form about $80 \%$ of bed; basalt component of pebble gravel about $40 \%$ at $30^{\prime}-$ depth, decreasing gradually to $20 \%$ at $50^{\prime}$-depth, basalt in coarse-to-medium sand decreases gradually from $30 \%$ at $30^{\prime}$-depth to $5 \%$ at $50^{\prime}$ depth, almost no silt present.

Ringold Formation:

Gravel; mostly exotic rock-types; fine-tocoarse from 1/4" to 6" in diameter, although mainly pebbles with occasional cobbles, in a medium-clean micaceous, quartzose sand matrix; upper $10^{\prime}$ of this gravel is highly calcareous and gives strong reaction to acid; sand content 
TABLE II (continued)

\begin{tabular}{|c|c|c|}
\hline & $\frac{\text { Thickness }}{\text { Feet }}$ & $\frac{\text { Depth }}{\text { Feet }}$ \\
\hline \multicolumn{3}{|l|}{$\begin{array}{l}\text { increases to } 55 \% \text { of sample in } 57^{\prime} \text { to } 60^{\prime} \text { zone, } \\
\text { remainder being gravel. }\end{array}$} \\
\hline $\begin{array}{l}\text { Gravel, exotic-type, subrounded-to-subangular; } \\
\text { has thin slit and clay zones in bottom foot } \\
\text { of bed. }\end{array}$ & 4 & 67 \\
\hline $\begin{array}{l}\text { Clay, light-tan; contains a few } 1 / 2 \text { " angular } \\
\text { pebbles. }\end{array}$ & 5 & 72 \\
\hline $\begin{array}{l}\text { Clay, light-tan, finely micaceous, slightly } \\
\text { silty. }\end{array}$ & 9 & 81 \\
\hline $\begin{array}{l}\text { Clay, light-tan, slightly silty, has a few } \\
1 / 6 " \text { to } 1 / 4 " \text { diameter rounded-to subrounded } \\
\text { indurated claystone nodules. }\end{array}$ & 3 & 84 \\
\hline $\begin{array}{l}\text { Gravel, granule and pebble, in a silty clay } \\
\text { clay matrix; approximate percentages: gran- } \\
\text { ule gravel, } 75 \text {; pebble gravel, 15; silty clay, } \\
\text { l0; rock particles are about half exotic and } \\
\text { half basalt, all rounded-to-subrounded. }\end{array}$ & 3 & 87 \\
\hline $\begin{array}{l}\text { Siltstone, light-tan, clayey, very finely } \\
\text { micaceous. }\end{array}$ & 4 & 91 \\
\hline $\begin{array}{l}\text { Sand, quartzose and micaceous, medium-to-fine, } \\
\text { well-sorted, over } 90 \% \text { siliceous, and gravel } \\
\text { mainly of dark exotic-types mostly about } 1 / 2^{\prime \prime} \\
\text { to } 1-1 / 2^{\prime \prime} \text { in diameter; gravel about } 30 \% \text { of } \\
\text { sample in } 91^{\prime}-\text { to } 96^{\prime}-\text { zone increasing to } 50 \% \\
\text { in the } 96^{\prime}-\text { to } 99^{\prime}-z o n e .\end{array}$ & 8 & 99 \\
\hline $\begin{array}{l}\text { Sand, silty and clayey, and gravel; gravel, } \\
\text { maximum diameter } 1 " \text {, forms approximately } 20 \% \\
\text { of sample; rude } 1 / 8 " \text {-thick weathering rind on } \\
\text { basalt pebbles. }\end{array}$ & 3 & 102 \\
\hline $\begin{array}{l}\text { Sand, quartose and micaceous, and gravel, as in } \\
91^{\prime}-\text { to } 96^{\prime} \text {-zone; good weathering rind on } \\
\text { basalt. }\end{array}$ & 4 & 106 \\
\hline $\begin{array}{l}\text { Gravel, sandy as in } 91^{\prime}-\text { to } 99^{\prime} \text {-foot bed except } \\
\text { that gravel component has increased to } 80 \% \text { of } \\
\text { sample; gravel in lower } 6^{\prime} \text { increases in size to } \\
\text { maximum diameter of } 4 " \text { and average diameter of } \\
2-1 / 2 " \text {; larger gravel is about } 20 \% \text { basalt having } \\
\text { weathering rinds. }\end{array}$ & 10 & 116 \\
\hline
\end{tabular}


TABLE II (continued)

\begin{tabular}{|c|c|c|}
\hline & $\frac{\text { Thickness }}{\text { Feet }}$ & $\frac{\text { Depth }}{\text { Feet }}$ \\
\hline $\begin{array}{l}\text { Sand, quartzitic and micaceous, medium-to- } \\
\text { fine, well-sorted, medium-to-heavy response } \\
\text { to acid test. }\end{array}$ & 4 & 120 \\
\hline $\begin{array}{l}\text { Siltstone, gravelly and slightly clayey; } \\
\text { gravel of } 1 / 4^{\prime \prime} \text { diameter forms } 40 \% \text { of bed in } \\
120^{\prime}-\text { to } 123^{\prime}-\text {-zone, is absent in } 123^{\prime}-\text { to } \\
126^{\prime}-z \circ n e \text { and increases to } 50 \% \text { of the sample } \\
\text { in } 126^{\prime}-\text { to } 130^{\prime}-z o n e, \text { where the maximum } \\
\text { diameter is } 3^{\prime \prime} \text {, gravel is mainly exotic types, } \\
\text { and sand is siliceous. }\end{array}$ & 10 & 130 \\
\hline $\begin{array}{l}\text { Sand, silty; contains about } 3 \% \text { subrounded } \\
\text { granule gravel. }\end{array}$ & 6 & 136 \\
\hline $\begin{array}{l}\text { Gravel, sandy and bouldery; gravel forms about } \\
80 \% \text { of bed, is } 50 \% \text { granules, and is composed } \\
\text { mainly of dark exotic rocks; cemented sand } \\
\text { coatings on pebbles and excellent } 1 / 8^{\prime \prime} \text {-thick } \\
\text { rinds on basalts. }\end{array}$ & 5 & 141 \\
\hline $\begin{array}{l}\text { Sand, fine-to-medium, micaceous, about } 90 \% \\
\text { clear angular-to-subangular quartz, about } 2 \% \\
\text { basalt, and estimated 1\% calcareous grains; } \\
\text { very reactive to acid test; a sand interbed } \\
\text { in gravel of } 136^{\prime}-\text { to } 165^{\prime} \text {-unit. }\end{array}$ & 3 & 144 \\
\hline $\begin{array}{l}\text { Gravel, pebble and boulder, in a clayey sand; } \\
\text { subrounded gravel, mainly of exotic types, } \\
\text { forms } 50 \% \text { of bed in } 144^{\prime} \text { - to } 156^{\prime} \text {-zone and } \\
\text { increases to } 80 \% \text { in } 156^{\prime} \text { - to } 165^{\prime} \text {-zone. }\end{array}$ & 21 & 165 \\
\hline $\begin{array}{l}\text { Gravel, boulder, cobble, and pebble; pebble } \\
\text { gravel is mainly } 1 / 2 " \text { to } 1 " \text { in diameter. }\end{array}$ & 6 & 171 \\
\hline $\begin{array}{l}\text { Silt, clayey, gray-tan; contains about } 5 \% \\
\text { angular granules--both exotics and basalt; } \\
\text { fewer rock particles in lower half of bed than } \\
\text { in upper half. }\end{array}$ & 6 & 177 \\
\hline $\begin{array}{l}\text { Clay, silty, gray-tan, has thin laminae of fine } \\
\text { gray-white volcanic ash near bottom of bed. }\end{array}$ & 13 & 190 \\
\hline Clay, blue-gray, has some greenish laminae. & 2 & 192 \\
\hline $\begin{array}{l}\text { Sand, basaltic; sand is } 80 \% \text { coarse-to-fine black } \\
\text { basalt, with } 10 \% \text { quartz and } 10 \% \text { calcareous } \\
\text { cement; some basalt and cemented fragments are } \\
1 / 4 " \text { in diameter; pyrite occurs as rare vesicle } \\
\text { filling in basalt pebbles; water-bearing. }\end{array}$ & 2 & 194 \\
\hline
\end{tabular}


TABLE II (continued)

Basalt of the Columbia River Group:
Basalt, black, dense-to-vesicular; contains
about 30 shaki banded and botryoidal
opaline vesicle fillings, together with some
clear feldspar and rounded and frosted quartz
vesicle fillings; secondary minerals abundant
in upper part of basalt; basalt is weathered
and clayey in upper part but fresh and hard
below 200' depth.

PENETRATION-RATE LOGS [9]

Foundation engineers commonly sample rocks by driving a split-spoon sampler into the ground with a standard weight dropped a standard distance (typically 140 pounds dropped 30"). The blows required to drive the sample 1 ' describe the rock's penetration resistance. Soft, unconsolidated rocks are penetrated rapidly (only a few blows per foot). Penetration-rate logs show the penetration rate at various depths. In addition, they usually show the water content of the split-spoon sample as percent of the dry weight. Penetration logs are available for the Fast Flux Test Facility (FFTF) and Nuclear Reactor areas.

\section{BOREHOLE GEOPHYSICAL STUDIES}

Borehole geophysical studies, sometimes called electric logs or wire-line logs, are obtained by lowering one or more sensors on a cable and recording their output at the surface. The Geohydrology Section, Research Division, College of Engineering, Washington State University, obtained 110 log suites from 82 wells and test holes in and around the Hanford Reservation. $\left[\begin{array}{lll}1 & 0-1 & -1\end{array}\right]$ Log suites by commercial logging companies have been obtained from some deep test holes. 


\section{LABORATORY TESTS}

Some rocks and soil samples collected during the drilling of wells and test holes are taken into a laboratory where selected properties are measured. The properties measured that contribute directly to our understanding of the flow continuum include grain-size distribution, relative density, permeability, porosity, and the elastic moduli.

Several hundred grain-size analyses have been made of samples from the 200 Areas. McHenry [14] reported the grainsize distribution, $\mathrm{pH}, \mathrm{CaCO}_{3}$ content, and cation exchange capacity of 504 samples from 38 wells distributed over the north half of the Hanford Reservation.

\section{PUMPING TESTS}

Pumping tests consist of (1) pumping a well and measuring the discharge and water-level drawdown both in the pumping well and in nearby observation wells and (2) turning off the pump and measuring the water-level recovery. By 1974 the results of 124 such tests had been reported for the wells in the Reservation or for wells near the Reservation. $[4,6]$

Drill-stem tests and injection tests have been conducted in a few wells.

\section{HYDROGRAPHS}

Hydrographs are the records of the water level in wells and test holes as a function of time or the record of river stage as a function of time. Kipp and Mudd[15] reported the hydrographs of wells on the Hanford Reservation for which more than two water-level measurements have been taken since 1944 . 
ELASTIC-WAVE DATA

Elastic-wave data consist of measurements of the velocity with which shear and compressional energy travel from a source to a receiver. Elastic energy radiates outward from the source as distinct waves. The compressional or "P" wave has small displacements along the direction of propagation of the wave; the shear or "S" wave has small displacements in a plane perpendicular to the direction or propagation of the wave. Compressional waves travel faster than the shear waves. 'In general wave velocities in dense, well-indurated rocks are faster than the wave velocities through softer, more porous, unconsolidated rocks.

Elastic-wave data for rocks of the Hanford Reservation derive from three types of measurements:

1. Measurements in one bore hole. The energy source and the receiver are suspended in the same hole or the energy source is in the hole and the receiver is at the surface nearby.

2. Measurements between holes. The energy source is in one drill hole and the receiver is at the same depth (usually) in another hole.

3. Refraction seismic surveys. The source transmits energy from a point at the surface or from a drill hole that is received by a number of receivers set up on the ground along a line radiating from the source. Arrival times and distance from the source are then used to interpret the velocities of the various beds through which the wave passes.

Brown and Raymond[16] described the results of refraction surveys conducted through 1964. Elastic-wave investigations have been conducted at each of the W.P.P.S.S. 
nuclear project sites and are included as part of the Preliminary Safety Analysis Reports.

\section{GEOLOGY}

A large amount of information is available regarding the general sequence and lithology of the rocks in the Pasco Basin. [7,17-23] In an earlier report $[8]$ the authors included a recent stratigraphic column.* This stratigraphic column differs from earlier interpretations [7] in that the Ellensburg Formation is excluded. Consequently, the Beverly members and Saddle Mountain Basalt members are also excluded.

From older-to-younger we find in the Pasco Basin the Yakima Basalt Formation, the Ringold Formation, Quaternary Glaciofluviatile Sands and Gravels, and unconsolidated Holocene deposits and ash beds. Each of these is discussed below.

\section{YAKIMA BASALT FORMATION}

This formation is the uppermost formation in the Columbia River Basalt group. The Pasco Basin is a synclinal basin that developed when the basalts folded. The upper surface of the Yakima Basalt formation thereby provided the floor upon which the sediments were deposited.

The Yakima Basalt Formation consists of relatively thick basalt flows separated by beds of tuffs and tuffaceous sandstones. These interbeds also included beds of sand and gravel, clay, diatomaceous material, and shale. Where the top of the formation consists of sedimentary rocks, they may be confused with the overlying sediments. Brown and

\footnotetext{
*Prepared by R. K. Ledgerwood (ARHCO).
} 
Haney [19] show clearly in a cross-section that the overlying sediments rest on interbeds at Wells 699-61-66, 65-60B, $53-55,37-42,31-31$, and 15-15.

\section{RINGOLD FORMATION}

In the Hanford area the Ringold Formation usually contains three units. $\left[\begin{array}{lll}20-23\end{array}\right]$ These are the lower clays, the middle conglomerates, and the upper silts and sands. In many areas at Hanford there is evidence that the lowermost beds of the Ringold Formation have been tilted.

The three-unit division cannot be applied indiscriminately at Hanford since it is an oversimplification.

1. Lower clay unit. The lower clay unit is not exposed. It is known only from wells. It consists of blue- and green-colored silts and clayey silts. Some beds of gravel and sand are interbedded with the blue clays and in some places are the predominant rocks. These rocks appear to be lacustrine sediments. Newcomb[24] believed they accumulated below altitudes of 290'. However, driller logs of some wells $(e . g ., 699-32-62)$ suggest that the clays may have filled the basin to altitudes higher than $400^{\prime}$. Wells in a north-south strip near the white Bluffs have penetrated two conglomerates either of which could be the middle unit. They also penetrate two blue-clay sequences which fit the description of the lower unit. Wells near Rattlesnake Hills penetrate a conglomerate that overlies the Yakima Basalt Formation.

2. Middle conglomerate unit. The conglomerate unit extends from a variable altitude of about $290^{\prime}$ upward for about 165'. According to Newcomb, [24] 
the conglomerate occurs in a line or strip about 10 miles wide and 50 miles long, between Sentinel Gap and Wallula Gap and running through the Hanford Reservation. It is a rather uniform aggregation of well-rounded pebbles and cobbles and some small boulders. The space between the pebbles and cobbles and some small boulders are almost completely filled by a matrix of medium-to-fine subrounded and angular-siliceous sand. The pebbles and cobbles are about 65\% quartz and other metamorphic, granite, and porphyritic volcanic rocks and $35 \%$ basaltic rocks. The sand is largely quartzose. Sand lenses and beds are common while lenses of sandy silt are rare.

The position, shape, thickness, and lithology of the conglomerate unit indicates that it represents a river-laid train of gravel in which quietwater sediments had been deposited and which were removed in part before deposition of the coarseclastic sediment began.

Laterally (northwest and southwest) with respect to the main body of the conglomerate, its stratigraphic interval is occupied by fine-grained deposits.

3. Upper silts and sands. The upper portion of the Ringold Formation does not contain a marked lithology type. It consists of intergraded layers of fine sandstone, siltstone, and claystone, some zones of which attain thicknesses of 20 to $40^{\prime}$. Newcomb ${ }^{[24}$ believed these sediments were laid down in a large lake. These upper silts and sands are capped in certain areas by a caliche layer. 
PALOUSE SOIL

In portions of the Hanford Reservation between the Ringold Formation and the overlying glaciofluviatile sediment lies a layer of soil developed upon the eroding surface of the Ringold Formation. For the most part it is a calcareous sand and silt derived from the Ringold Formation. In places it is an eolian deposit of well-sorted angularto-subangular, slightly frosted, buff-colored silt that is as much as 70' thick. Newcomb[25] named similar eolian deposits in the Walla Walla and Umatilla River Basins the Palouse Formation.

\section{GLACIOFLUVIATILE DEPOSITS}

The glaciofluviatile deposits are divided into the Pasco Gravels and the Touchet Silts. The Touchet Silts appear to be a quiet water facies of the Pasco Gravels.

The Pasco Gravels were deposited by an aggrading stream. They are predominantly coarse-grained gravels, cobbles, and sands with cut-and-fill structure. The Touchet Silts are fine-grained deposits including some clays and fine sand deposited in slowly moving water or perhaps in temporary lakes. Both the Pasco Gravels and the Touchet silts are unconsolidated. Cement is rare in both of them. The gravels contain a predominance of basalt fragments.

\section{HOLOCENE DEPOSITS AND ASH BEDS}

With the exception of the eolian deposits and ash falls, the land surface of the Hanford area has been degrading since the deposit of the Touchet silts, and in all probability erosion has removed considerable material. As a consequence, Holocene deposits consist of alluvium along the Columbia River, talus and fan deposits along Rattlesnake 
Hills, Gable Mountain, and Gable Butte. Extensive areas of dunes mark the eolian deposits.

Three layers of volcanic ash have been recognized in outcrops around the Hanford Reservation, but none have been specifically detected at a well site.

\section{HYDRAULIC CONCEPTS}

POROSITY

The porosity of a material is defined as the ratio of the volume of the void space $\left(U_{v}\right)$ to the bulk volume $\left(U_{b}\right)$ of the porous medium; this is,

$$
\text { porosity }=E=\frac{U_{V}}{U_{b}}=\frac{1-U_{S}}{U_{b}}
$$

where $U_{s}$ is the volume of solids within $U_{b}$.

From the standpoint of flow through a porous medium one is concerned only with those pores that are interconnected. The above concept of porosity involves the sum total of all pore space. A more useful quantity in flow studies is the concept of effective porosity $f_{e}$ which is defined as the ratio of interconnected pore volume $\left(U_{v}\right)_{e}$ to the total volume of the medium; that is,

$$
f_{e}=\frac{\left(U_{v}\right)_{e}}{U_{b}}
$$

STORAGE COEFFICIENT

The storage coefficient indicates the relationship between the changes in the quantity of water stored in an aquifer and the corresponding changes in water table or piezometric surface elevation. It can be defined as the volume of water released from storage, or taken into storage, 
per unit of surface area of aquifer per unit change in water table elevation or piezometric head. In confined aquifers the storage coefficient involves the interplay of two elastic effects--compression of the aquifer and expansion of the contained water--when the head is reduced during pumping. In unconfined aquifers the storage coefficient represents the result of dewatering of interconnected pores and thus in the limit approaches the effective porosity.

HYDRAULIC CONDUCTIVITY

The hydraulic conductivity of a flow continuum is a measure of the capacity of the interconnected pores to transmit water. These pores include the intergranular space between particles and the space generated when the rock mass fractures. The effective porosity of unconsolidated rocks derives from the intergranular space, whereas the effective porosity of indurated rocks derives primarily from fractures.

In general the hydraulic conductivity of an unconsolidated mass decreases as the mass compacts. It is further decreased when cement fills the voids. When the rocks fracture, the hydraulic conductivity of the rock mass increases. In fine-grained deposits the hydraulic conductivity due to fracture porosity may be orders of magnitude greater than that due to intergranular porosity.

The sediments of the Pasco Basin range from loose, unconsolidated masses that will not hold an unsupported vertical face, to well-indurated, cemented rocks that form cliffs and stand open in drill holes without support. 
TRANSMISSIVITY

Transmissivity ( $T$ ) is a measure of an entire lithologic entity's (formation, part of a formation, group of formations) capacity to transmit water horizontally under a unit hydraulic gradient. In an isotropic homogeneous porous medium with thickness (b) and the horizontal component of hydraulic conductivity $(K)$, the transmissivity of any vertical column of saturated rock is

$$
\mathrm{T}=\mathrm{Kb}
$$

For rocks with multiple layers each of thickness $b_{i}$ and having different hydraulic conductivities $\left(\mathrm{K}_{i}\right)$

$$
T=\sum_{l=1}^{n} K_{i} b_{i}
$$

- If we know $T$ and $b$ or $\sum_{l=1}^{n} b_{i}$, then we may compute the mean horizontal hydraulic conductivity $(\bar{K})$.

\section{LABORATORY AND FIELD DETERMINATIONS \\ OF HYDRAULIC PROPERTIES}

As noted previously in this report much is known about the geology and hydraulic characteristics of the sediment underlying the Hanford Reservation. This section of the report was prepared by compiling, condensing, and interpreting results from all tests conducted on the sediment overlying the top surface of the basalt. From a hydrologic standpoint this zone between the top of the basalt and the water table is usually termed the Hanford unconfined aquifer. 
POROSITY

Porosity measurements in sediments underlying the Hanford Reservation are not abundant. The effective porosity of the glaciofluviatile sediments is usually less than $10 \%$. Lithologic differences suggest that the rocks of the Ringold Formation should have a lower porosity than those of the glaciofluviatile deposits. The elastic-wave velocity contrast between the Ringold Formation and the glaciofluviatile deposits also suggests that the porosity of the rocks that make up the Ringold Formation must be appreciably smaller.

\section{HYDRAULIC CONDUCTIVITY}

The hydraulic conductivity has been measured in the laboratory for a few samples collected from wells or test holes. A few constant-head injection tests have also been conducted in wells to determine hydraulic conductivity. The results can be summarized as follows:

$\frac{\text { Material }}{\text { Sandy gravel and gravels }}$
Sand
Clay

$\frac{K(f t / d a y)}{250 \quad-4000}$

The areal distribution of the horizontal hydraulic conductivity has been computed using data from 48 pumping tests. These data were processed using the Transmissivity Iterative Routine (TIR) developed by Battelle Pacific Northwest Laboratories to obtain a Transmissivity distribution. This distribution was used in conjunction with aquifer thickness data (aquifer thickness = depth to aquifer bottom-depth to water) to obtain a hydraulic conductivity distribution. The depth to the bottom of the aquifer (Figure 2) was obtained from driller logs and then a 


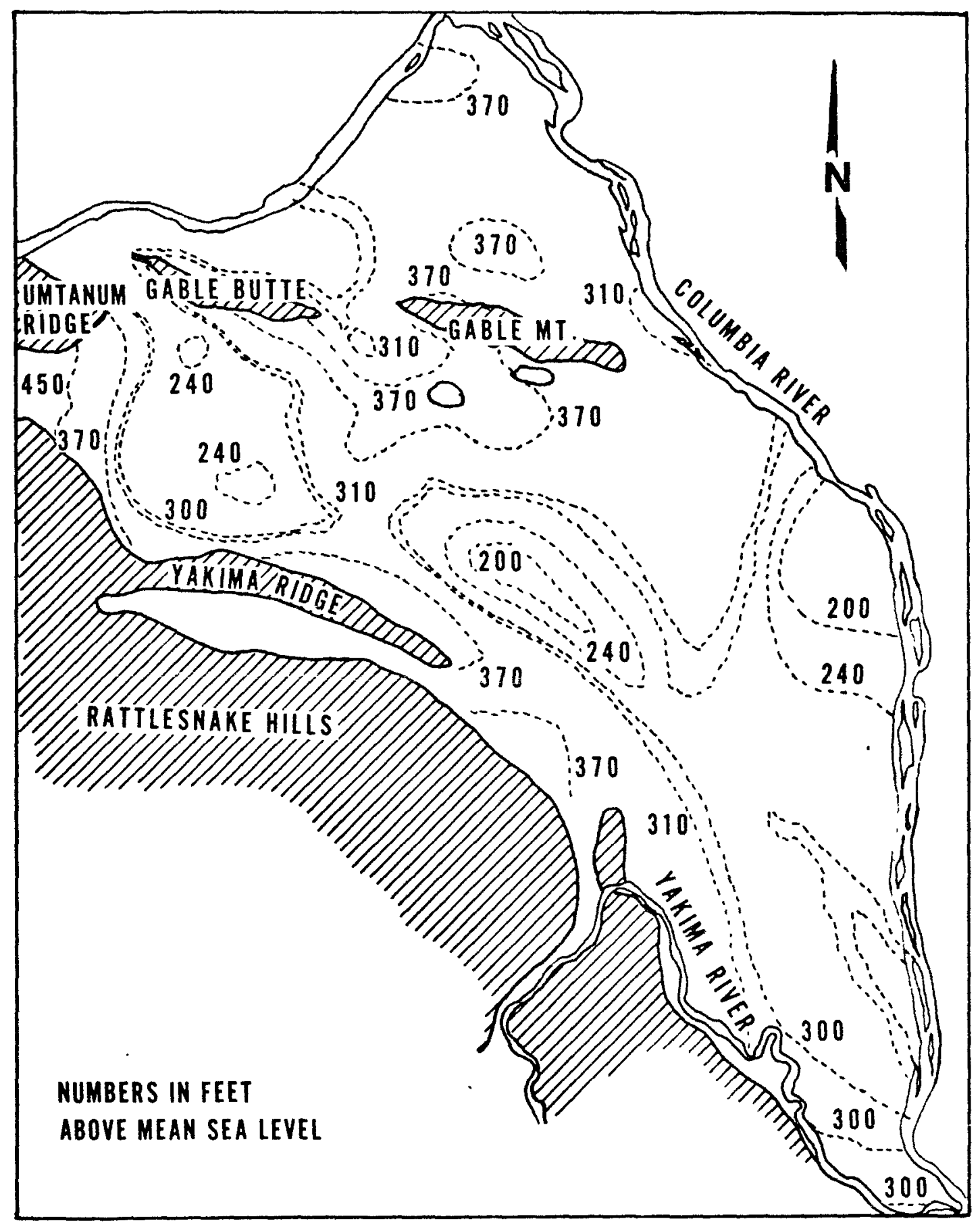

\section{FIGURE 2}

COMPUTER-GENERATED MAP OF THE BOTTOM OF THE UNCONFINED AQUIFER 


\section{ARH-C-00007,}

contour map was generated using a computer. The areal distribution of hydraulic conductivity obtained by this technique (Plate 1 ) is not representative of average hydrauIic conductivities in the unconfined aquifer but represents the hydraulic conductivity of the intervals pump tested. Table III lists the wells used in preparing Plate 1.

\section{TRANSMISSIVITY VALUES}

Transmissivity values can be obtained by using the hydraulic conductivity values measured in the laboratory and assuming a saturated thickness for the aquifer. Such a procedure is not very accurate. This is especially true when we are dealing with values measured in the Ringold Formation. Since we believe that the Ringold Formation is fractured, the low values obtained in many laboratory tests reflect only the intergranular pores and therefore do not reflect the true value of the hydraulic conductivity of the flow continuum.

Two reports $[26,27]$ show the transmissivity as determined by analyses of the relationships between river-levelstage changes and the change of water levels in wells near the river. The transmissivity values reported are summarized in Table IV.

Transmissivity data obtained from 48 pumping tests were fed to the TIR Model to obtain a Transmissivity distribution (Plate 2). The wells used are those shown in Table III.

\section{STORAGE COEFFICIENT}

Storage coefficient must be determined from pumping tests. Unfortunately, the techniques and necessary input data for the calculation of storage coefficient distribution for the unconfined aquifer have not yet been developed. 


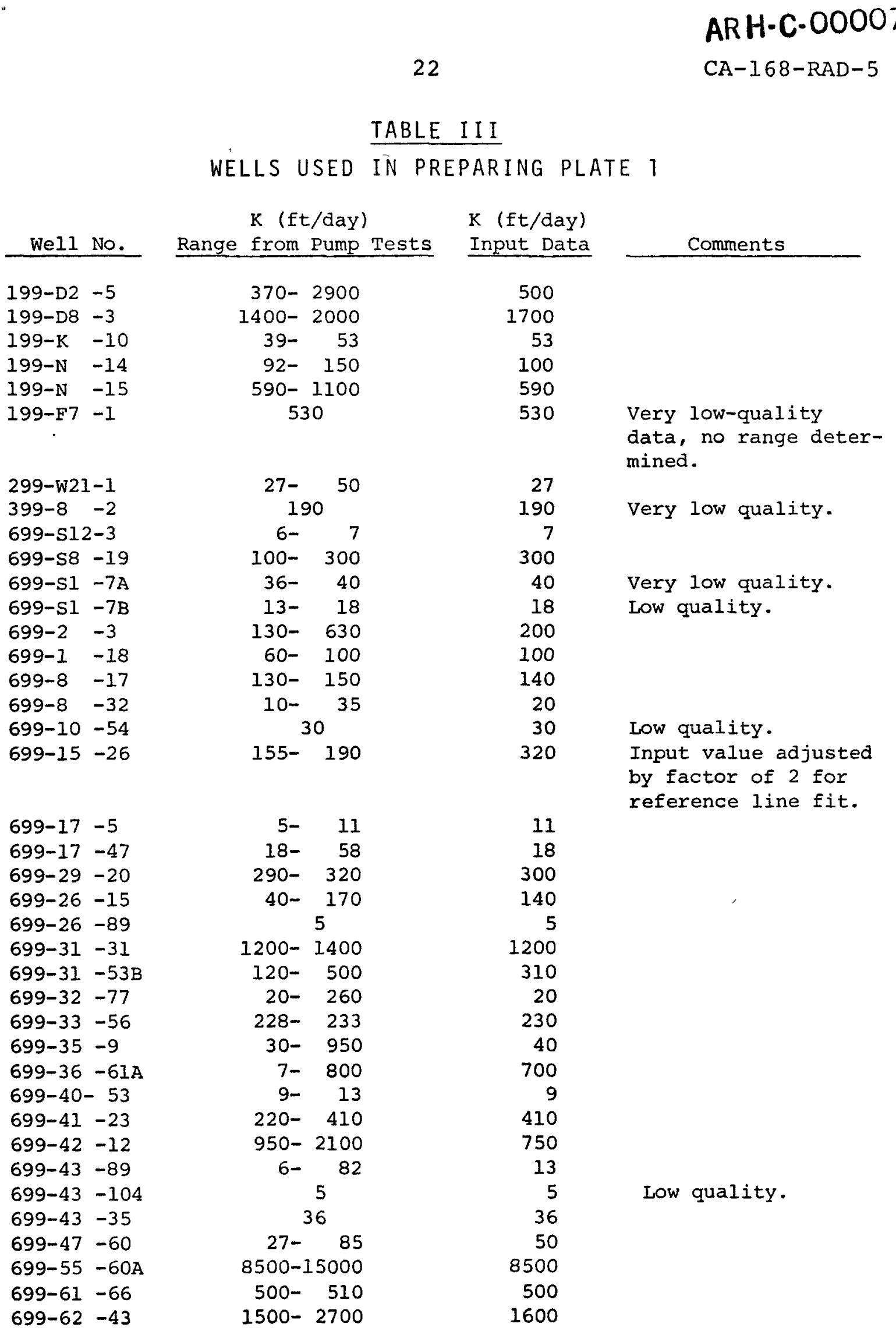


TABLE III (continued)

$K$ (ft/day) $K$ (ft/day)

Range from Pump Tests

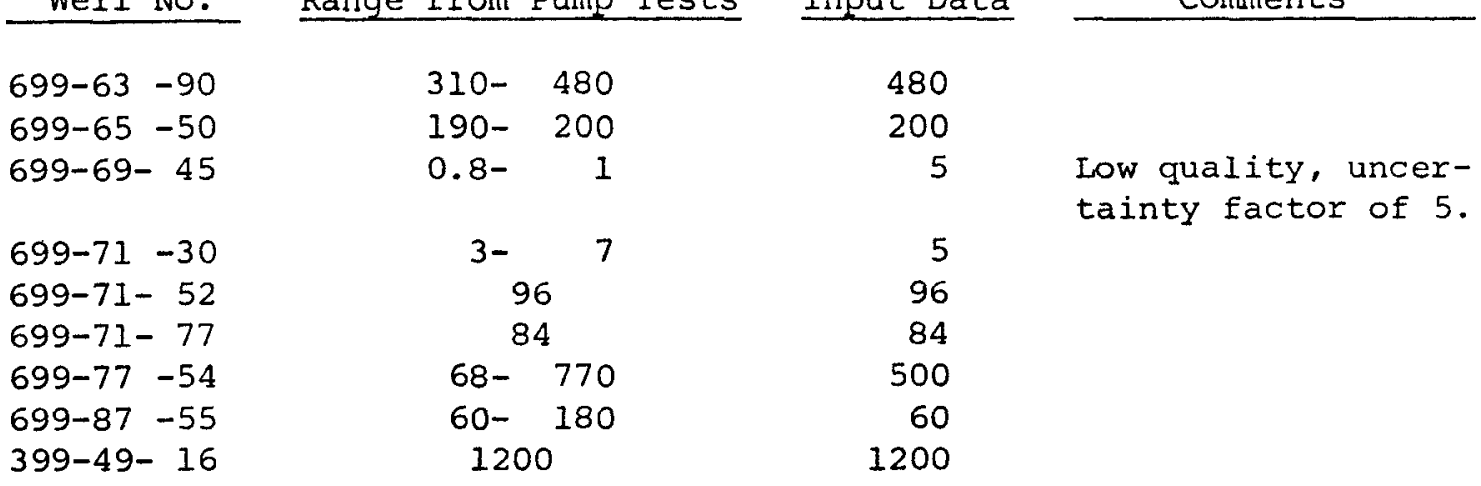

TABLE IV

TRANSMISSIVITIES FROM RIVER-STAGE FLUCTUATIONS

\begin{tabular}{|c|c|c|c|c|c|}
\hline Reach of Columbia & Formula & Tran & $\frac{\mathrm{smis}}{\mathrm{ft^{2 }}}$ & sivity & $\begin{array}{l}\text { Ref. } \\
\text { Source }\end{array}$ \\
\hline $100 \mathrm{~N}$ Area & Glaciofluviatile & 4000 & to & 8000 & 26 \\
\hline North of Gable Mountain & Glaciofluviatile & 81000 & to & $3 i 0000$ & 3 \\
\hline North of Gable Mountain & $\begin{array}{l}\text { Glaciofluviatile } \\
\text { Ringold }\end{array}$ & 17000 & to & 32000 & 3 \\
\hline Town of Hanford & Ringold & 2000 & to & 35000 & 3 \\
\hline West boundary to $100 \mathrm{~K}$ & Glaciofluviatile & & 270 & & 27 \\
\hline $100 \mathrm{k}-100 \mathrm{H}$ Areas & $\begin{array}{l}\text { Glaciofluviatile } \\
\text { Ringold }\end{array}$ & & & & 27 \\
\hline $100 \mathrm{H}$ Area-Ringold & Ringold (?) & & & 00 & 27 \\
\hline Ringold-Richland & Glaciofluviatile & & 1600 & & 27 \\
\hline
\end{tabular}

Values for the storage coefficient at Hanford are few and not of great accuracy. They range from 0.00007 to 0.2 (Table V).

For the purposes of groundwater flow and radionuclide transport simulation modeling, the effective porosity over 
TABLE V

STORAGE COEFFICIENT VALUES ( $S$ ) DETERMINED FROM

PUMPING TESTS AT THE HANFORD RESERVATION

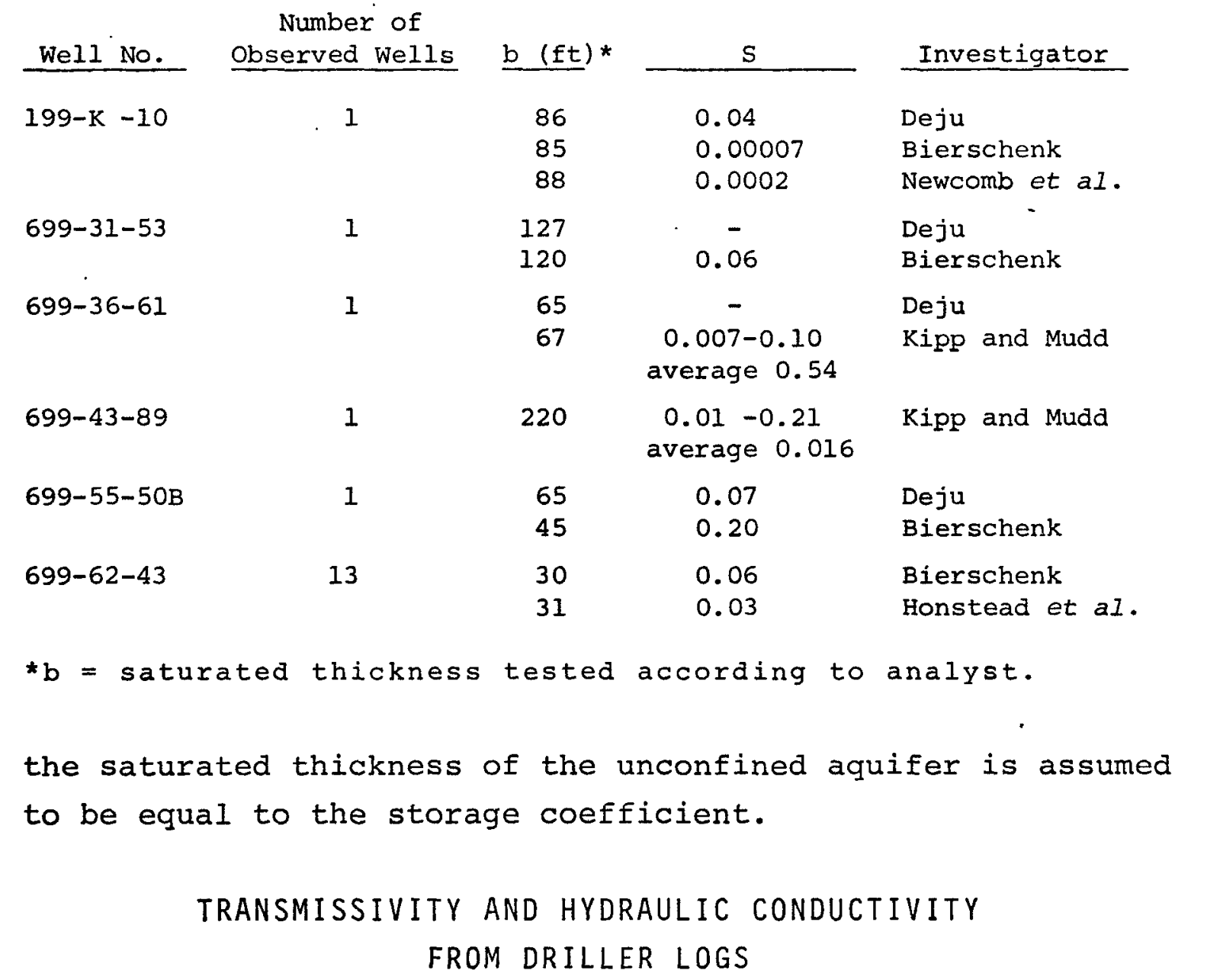

Transmissivity and hydraulic conductivity values can be obtained from an examination of driller logs. This is the procedure we used:

1. On the drillers' logs we recognized five relative permeability units. To these units were assigned relative numbers (NI) as follows: 


$\begin{array}{ll}\text { NI } & \text { Lithology from Drillers' Logs } \\ 10^{4} & \text { Cobbles, coarse gravel, pebbles } \\ 10^{3} & \text { Gravel, sand and gravel } \\ 10^{2} & \text { Sand } \\ 10 & \text { Fine sand, sand and silt } \\ 1 & \text { Clay, clay and silt, sandy clay }\end{array}$

2. We then color-coded each driller's log to show the number $\mathrm{Nl}$ for each interval described by the driller.

3. For each well location the January 1973 water-table elevation was obtained from the water-table map. This elevation was used to determine the upper limit of saturation.

4. For the saturated interval the number $\mathrm{Nl}$ of each interval described by the driller was multiplied by the interval's thickness. These products were then summed to produce another number $(\mathrm{N} 2)$ representing the relative transmissiveness of the saturated sedimentary rocks described by the driller. Table VI contains the values of N2 thus obtained. 
TABLE VI

SATURATED THICKNESS, RELATIVE NUMBER N2, AND ESTIMATED TRANSMISSIVITY AND HYDRAULIC CONDUCTIVITY BASED ON DRILLERS' LOGS

\begin{tabular}{|c|c|c|c|c|c|c|c|c|}
\hline \multirow[b]{4}{*}{ Well } & \multirow[b]{4}{*}{ No. } & \multicolumn{4}{|c|}{ Saturated Thickness } & \multicolumn{3}{|c|}{$\begin{array}{c}\text { Estimated Transmissivity } \\
\text { from Drillers' Logs }\end{array}$} \\
\hline & & \multicolumn{2}{|c|}{ Total Feet } & \multirow{2}{*}{\multicolumn{2}{|c|}{$\begin{array}{c}\text { Penetrated } \\
\text { by Well } \\
\end{array}$}} & \multicolumn{3}{|c|}{ Estimated } \\
\hline & & \multirow{2}{*}{$\begin{array}{r}\text { From } \\
\text { Log } \\
\end{array}$} & \multirow{2}{*}{$\begin{array}{l}\text { Estimated } \\
\text { from Map } \\
\end{array}$} & & & \multirow{2}{*}{$\begin{array}{l}\mathrm{N} 2 \\
\times \quad 1000 \\
\end{array}$} & \multirow{2}{*}{$\begin{array}{c}\text { "T" }(\mathrm{ft} 2 / \mathrm{d}) \\
\times 1000 \\
\end{array}$} & \multirow{2}{*}{$\begin{array}{l}\text { Estimated } \\
\text { "K" (Et/d) } \\
\end{array}$} \\
\hline & & & & $\mathrm{ft}$ & $\frac{8}{8}$ & & & \\
\hline 199-D2 & -5 & - & 290 & 30 & 10 & $180+$ & $35+$ & 1200 \\
\hline $199-\mathrm{F} 5$ & -6 & & 310 & 161 & 52 & $9.4+$ & $1.9+$ & 12 \\
\hline 199-H4 & -2 & 227 & & 227 & 100 & 3.7 & 7.2 & 32 \\
\hline $299-E 26$ & $6-1$ & 9 & & 9 & 100 & 9.0 & 1.7 & 190 \\
\hline 299-E28 & $3-9$ & - & 80 & 60 & 75 & $75+$ & $15+$ & 250 \\
\hline 299-WII & $1-2$ & 255 & - & 255 & 100 & 87 & 17 & 67 \\
\hline $299-W 22$ & $2-14$ & - & 268 & 18 & 7 & $68+$ & $13+$ & 720 \\
\hline $699-S 31$ & $1-1$ & 102 & - & 102 & 100 & 66 & 12 & 120 \\
\hline $699-530$ & O-El 5A & - & 150 & 27 & 18 & $86+$ & $16+$ & 590 \\
\hline $699-\$ 29$ & $9-\mathrm{E} 12$ & - & 150 & 40 & 20 & $40+$ & 8. $0+$ & 300 \\
\hline $699-523$ & $3-26$ & - & 100 & 29 & 29 & $70+$ & $14+$ & 480 \\
\hline 699-S19 & 9-E13 & - & 150 & 32 & 21 & $50+$ & $10+$ & 310 \\
\hline $699-519$ & $9-11$ & - & 80 & 25 & 31 & $25+$ & $4.9+$ & 200 \\
\hline $699-S 18$ & $8-E 2$ & 170 & - & 170 & 100 & 130 & 25 & 150 \\
\hline 699-S14 & $4-2 C$ & 64 & - & 64 & 100 & 64 & 15 & 230 \\
\hline $699-S 12$ & $2-3$ & - & 200 & 52 & 26 & $52+$ & $10+$ & 190 \\
\hline $699-S 12$ & $2-29$ & 108 & - & 108 & 100 & 4.9 & 0.95 & 8.8 \\
\hline $699-56$ & $-E 14 A$ & 157 & - & 157 & 100 & 110 & 21 & 130 \\
\hline $699-56$ & $-E 4 C$ & 264 & - & 264 & 100 & 14 & 2.7 & 10 \\
\hline $699-1$ & -18 & - & 320 & 213 & 71 & $980+$ & $200+$ & 940 \\
\hline $699-2$ & -33 & 296 & - & $2 \dot{9} 6$ & 100 & 53 & 10 & 34 \\
\hline $699-3$ & -45 & 5 & - & 5 & 100 & 5.0 & 0.95 & 190 \\
\hline $699-8$ & -17 & - & 340 & 57 & 19 & $5.7+$ & $1.1+$ & 19 \\
\hline $699-9$ & $-E 2$ & 361 & - & 361 & 100 & 290 & 60 & 170 \\
\hline
\end{tabular}


TABLE VI (continued)

\begin{tabular}{|c|c|c|c|c|c|c|c|c|c|}
\hline \multirow[b]{4}{*}{ Well } & \multirow[b]{4}{*}{ No. } & \multicolumn{4}{|c|}{ Saturated Thickness } & \multicolumn{3}{|c|}{$\begin{array}{c}\text { Estimated Transmissivity } \\
\text { from Drillers' Logs }\end{array}$} & \\
\hline & & \multicolumn{2}{|c|}{ Total Feet } & \multirow{2}{*}{\multicolumn{2}{|c|}{$\begin{array}{l}\text { Penetrated } \\
\text { by well }\end{array}$}} & \multirow{3}{*}{$\begin{array}{r}N 2 \\
\times \quad 1000 \\
\end{array}$} & \multirow{3}{*}{$\begin{array}{c}\text { Estimated } \\
\text { "T" }\left(\mathrm{ft} \mathrm{t}^{2} / \mathrm{d}\right) \\
\times 1000 \\
\end{array}$} & \multirow{3}{*}{$\begin{array}{l}\text { Estimated } \\
\text { "K" (ft/d) }\end{array}$} & \\
\hline & & From & Estimated & & & & & & \\
\hline & & Log & from Map & $\mathrm{ft}$ & 8 & & & & \\
\hline $699-10$ & $-\mathrm{E} 12$ & - & 330 & 315 & 95 & $210+$ & $41+$ & 140 & \\
\hline $699-14$ & $-E 6 \quad(Q \& T)$ & - & 340 & 295 & 87 & $1800+$ & $300+$ & 1000 & \\
\hline $699-14$ & -38 & 316 & - & 316 & 100 & 72 & 14 & 44 & \\
\hline $699-15$ & $-15 A$ & 400 & - & 400 & 100 & 190 & 38 & 95 & \\
\hline $699-15$ & -26 & - & 390 & 225 & 58 & $780+$ & $260+$ & 1200 & \\
\hline $699-17$ & -5 & - & 390 & 43 & 11 & $28+$ & $4.5+$ & 100 & \\
\hline $699-20$ & $-E 5 P$ & - & 320 & 175 & 55 & $1200+$ & $220+$ & 1300 & \\
\hline $699-20$ & -20 & - & 450 & 66 & 15 & $160+$ & 31 & 470 & \\
\hline $699-20$ & -39 & 208 & - & 208 & 100 & 980 & 190 & 910 & $N$ \\
\hline $699-24$ & $-1 P$ & 283 & - & 283 & 100 & 65 & 13 & 46 & \\
\hline $699-24$ & -33 & - & 450 & 51 & 11 & $34+$ & $6.5+$ & 130 & \\
\hline $699-24$ & -46 & 383 & - & 383 & 100 & 210 & 42 & 110 & \\
\hline $699-25$ & -70 & - & 350 & 276 & 79 & $120+$ & $23+$ & 83 & \\
\hline $699-26$ & -15 & - & 480 & 160 & 33 & $200+$ & $40+$ & 250 & \\
\hline $699-26$ & -89 & 295 & - & 295 & 100 & 660 & 130 & 440 & \\
\hline $699-27$ & -8 & 457 & - & 457 & 100 & 170 & 22 & 48 & \\
\hline $699-28$ & -40 & 315 & - & 315 & 100 & 470 & 93 & 300 & \\
\hline $699-28$ & -52 & 413 & - & 413 & 100 & 100 & 20 & 48 & \\
\hline $699-29$ & -78 & 314 & - & 314 & 100 & 950 & 19 & 61 & \\
\hline 699-31 & -31 & 502 & - & 502 & 100 & 1200 & 220 & 440 & \\
\hline $699-31$ & $-53 B$ & - & 290 & 127 & 44 & $89+$ & $1.7+$ & 13 & 2 \\
\hline $699-31$ & -65 & - & 330 & 209 & 63 & $87+$ & $1.6+$ & 7.7 & $\stackrel{1}{1} I$ \\
\hline $699-32$ & -22 & - & 440 & 65 & 15 & $6.5+$ & $1.3+$ & 20 & के \\
\hline $699-32$ & -62 & - & 260 & 224 & 86 & $25+$ & 4.0 & 18 & 1 \\
\hline $699-32$ & -70 & - & 320 & 142 & 44 & $59+$ & $12+$ & 85 & $\$ 0$ \\
\hline 699-32 & -72 & 362 & - & 362 & 100 & 1500 & 280 & 770 & i \\
\hline $699-32$ & -77 & - & 280 & 116 & 41 & $40+$ & $8.0+$ & 69 & \\
\hline
\end{tabular}




\section{TABLE VI (continued)}

\begin{tabular}{|c|c|c|c|c|c|c|c|c|}
\hline \multirow[b]{4}{*}{ Well } & \multirow[b]{4}{*}{ No. } & \multicolumn{4}{|c|}{ Saturated Thickness } & \multicolumn{3}{|c|}{$\begin{array}{c}\text { Estimated Transmissivity } \\
\text { from Drillers' Logs }\end{array}$} \\
\hline & & \multicolumn{2}{|c|}{ Total Feet } & \multirow{2}{*}{\multicolumn{2}{|c|}{$\begin{array}{l}\text { Penetrated } \\
\text { by Well } \\
\end{array}$}} & \multirow{3}{*}{$\begin{array}{r}\text { N2 } \\
\times 1000 \\
\end{array}$} & Estimated & \multirow[b]{2}{*}{ Estimated } \\
\hline & & From & Estimated & & & & "T" $\left(f t^{2} / d\right)$ & \\
\hline & & Log & from Map & ft & 8 & & $\times 1000$ & "K" $(\mathrm{ft} / \mathrm{d})$ \\
\hline $699-33$ & -56 & - & 250 & 114 & 46 & $130+$ & $25+$ & 220 \\
\hline $699-34$ & $-39 A$ & - & 270 & 36 & 13 & $7.2+$ & $0.14+$ & 3.9 \\
\hline $699-34$ & -41 & - & 250 & 13 & 5.2 & $0.94+$ & $0.18+$ & 14 \\
\hline $699-34$ & -42 & - & 280 & 47 & 17 & $47+$ & $7.3+$ & 160 \\
\hline $699-34$ & -51 & - & 240 & 61 & 25 & $57+$ & $1.1+$ & 18 \\
\hline $699-34$ & -88 & 477 & - & 477 & 100 & 130 & 25 & 52 \\
\hline $699-35$ & -9 & - & 400 & 61 & 15 & $12+$ & $2.3+$ & 38 \\
\hline $699-35$ & -66 & - & 200 & 89 & 45 & $6.1+$ & $0.12+$ & 1.3 \\
\hline $699-35$ & -70 & - & 200 & 93 & 47 & $44+$ & $8.5+$ & 91 \\
\hline $699-35$ & -78 & - & 270 & 101 & 37 & $59+$ & $11+$ & 110 \\
\hline $699-36$ & $-46 R$ & - & 260 & 82 & 32 & $280+$ & $56+$ & 680 \\
\hline $699-36$ & $-61 A$ & - & 210 & 54 & 26 & $5.4+$ & $1.0+$ & 19 \\
\hline $699-36$ & -610 & - & 210 & 198 & 94 & $80+$ & $16+$ & 81 \\
\hline $699-36$ & -93 & 490 & - & 490 & 100 & 110 & 21 & 43 \\
\hline $699-37$ & -43 & - & 250 & 237 & 95 & $510+$ & $100+$ & 420 \\
\hline $699-37$ & $-82 A$ & 269 & - & 269 & 100 & 230 & 34 & 130 \\
\hline $699-38$ & -65 & 150 & - & 150 & 100 & 93 & 18 & 120 \\
\hline $699-38$ & -70 & 135 & - & 135 & 100 & 160 & 22 & 160 \\
\hline $699-39$ & -39 & - & 210 & 86 & 41 & $0.086 t$ & $0.016+$ & 0.19 \\
\hline $699-39$ & -79 & - & 210 & 98 & 47 & $460+$ & $91+$ & 93 \\
\hline $699-40$ & -1 & 231 & - & 231 & 100 & 97 & 19 & 82 \\
\hline $699-40$ & -33 & - & 220 & 179 & 81 & $300+$ & $60+$ & 335 \\
\hline $699-40$ & -62 & - & 230 & 42 & 18 & $0.042+$ & $0.008+$ & 0.44 \\
\hline $699-41$ & -23 & - & 220 & 54 & 25 & $260 t$ & $51+$ & 940 \\
\hline $699-42$ & -12 & 152 & - & 152 & 100 & 63 & 12 & 79 \\
\hline $699-42$ & -42 & 118 & - & 118 & 100 & 300 & 60 & 510 \\
\hline $699-43$ & -42 & - & 110 & 19 & 17 & $1.9+$ & 0.38 & 20 \\
\hline
\end{tabular}


TABLE VI (continued)

\begin{tabular}{|c|c|c|c|c|c|c|c|c|}
\hline \multirow[b]{4}{*}{ Well } & \multirow[b]{4}{*}{ No. } & \multicolumn{4}{|c|}{ Saturated Thickness } & \multicolumn{3}{|c|}{$\begin{array}{l}\text { Estimated Transmissivity } \\
\text { from Drillers' Logs }\end{array}$} \\
\hline & & \multicolumn{2}{|c|}{ Total Feet } & \multicolumn{2}{|c|}{ Penetrated } & \multirow{2}{*}{\multicolumn{2}{|c|}{$\begin{array}{c}\text { Estimated } \\
\text { "T" }\left(\mathrm{ft}^{2} / \mathrm{d}\right)\end{array}$}} & \multirow{3}{*}{$\begin{array}{l}\text { Estimated } \\
\text { "K" (ft/d) }\end{array}$} \\
\hline & & From & Estimated & by & e11 & & & \\
\hline & & Log & from Map & ft & 8 & x 1000 & $\times 1000$ & \\
\hline $699-43$ & -89 & - & 420 & 139 & 33 & $14+$ & $2.8+$ & 20 \\
\hline $699-44$ & -64 & 123 & - & 123 & 100 & 470 & 95 & 770 \\
\hline $699-45$ & -69 & 83 & - & 83 & 100 & 6.3 & 1.2 & 14 \\
\hline $699-46$ & -21 & - & 220 & 205 & 93 & $590+$ & 120 & 580 \\
\hline $699-47$ & -35 & 28 & - & 28 & 100 & 200 & 30 & 110 \\
\hline $699-47$ & -60 & 40 & - & 40 & 100 & 13 & 2.5 & 63 \\
\hline $699-48$ & -71 & - & 75 & 67 & 89 & 400 & 80 & 1200 \\
\hline $699-49$ & -28 & - & 130 & 32 & 25 & $11+$ & $2.1+$ & 66 \\
\hline $699-49$ & -55 & 12 & - & 12 & 100 & 120 & 23 & 1900 \\
\hline $699-49$ & -57 & 18 & - & 18 & 100 & 110 & 22 & 1200 \\
\hline $699-49$ & -79 & 58 & - & 58 & 100 & 58 & 9.5 & 160 \\
\hline $699-50$ & $-28 \mathrm{~B}$ & - & 110 & 27 & 25 & $2.7+$ & $0.52+$ & 19 \\
\hline $699-50$ & -30 & 190 & - & 190 & 100 & 400 & 80 & 420 \\
\hline $699-50$ & -85 & 304 & - & 304 & 100 & 720 & 120 & 390 \\
\hline $699-51$ & -63 & - & 40 & 21 & 53 & 210 & 41 & 2000 \\
\hline $699-51$ & -75 & 180 & - & 180 & 100 & 760 & 150 & 830 \\
\hline $699-53$ & -47 & 14 & - & 14 & 100 & 140 & 27 & 1900 \\
\hline $699-53$ & -53 & 127 & - & 127 & 100 & 210 & 41 & 320 \\
\hline $699-54$ & -42 & 85 & - & 85 & 100 & 3 & 0.58 & 6.8 \\
\hline $699-54$ & -45 & - & 20 & 13 & 65 & $0.013+$ & $0.0025+$ & 0.19 \\
\hline $699-55$ & $-50 A$ & 52 & - & 52 & 100 & 280 & 46 & 880 \\
\hline $699-55$ & -76 & 44 & - & 44 & 100 & 22 & 4.3 & 98 \\
\hline $699-55$ & -89 & - & 180 & 60 & 33 & $60+$ & $12+$ & 200 \\
\hline $699-55$ & -95 & 95 & - & 95 & 100 & $4.5+$ & 0.85 & 8.9 \\
\hline $699-57$ & -83 & 175 & - & 175 & .100 & 54 & 8.5 & 49 \\
\hline $699-58$ & -24 & - & 250 & 10 & 4 & $1.0+$ & $0.19+$ & 19 \\
\hline $699-59$ & -58 & - & 100 & 15 & 15 & $1.5+$ & $0.29+$ & 19 \\
\hline
\end{tabular}




\section{TABLE VI (continued)}

\begin{tabular}{|c|c|c|c|c|c|c|c|c|}
\hline \multirow[b]{4}{*}{ Well } & \multirow[b]{4}{*}{ No. } & \multicolumn{4}{|c|}{ Saturated Thickness } & \multicolumn{3}{|c|}{$\begin{array}{c}\text { Estimated Transmissivity } \\
\text { from Drillers' Logs }\end{array}$} \\
\hline & & \multicolumn{2}{|c|}{ Total Feet } & \multirow{2}{*}{\multicolumn{2}{|c|}{$\begin{array}{c}\text { Penetrated } \\
\text { by well } \\
\end{array}$}} & \multirow{3}{*}{$\begin{array}{l}\mathrm{N} 2 \\
\times 1000 \\
\end{array}$} & \multirow{3}{*}{$\begin{array}{l}\text { Estimated } \\
\text { "T" }\left(\mathrm{ft}{ }^{2} / \mathrm{d}\right) \\
\times 1000 \\
\end{array}$} & \multirow{3}{*}{$\begin{array}{r}\text { Estimated } \\
\text { "K" (ft/d) } \\
\end{array}$} \\
\hline & & $\overline{\text { From }}$ & Estimated & & & & & \\
\hline & & Log & from Map & $\mathrm{ft}$ & $\frac{9}{6}$ & & & \\
\hline $699-71$ & -52 & - & 300 & 97 & 32 & $3.1+$ & $0.61+$ & 6.3 \\
\hline $699-71$ & -77 & - & 300 & 238 & 79 & $150+$ & $30+$ & 130 \\
\hline $699-72$ & -73 & - & 300 & 30 & 10 & $0.030+$ & $0.006+$ & 0.20 \\
\hline $699-72$ & -92 & - & 300 & 145 & 48 & $640+$ & $130+$ & 900 \\
\hline $699-74$ & -44 & 100 & - & 100 & 100 & 0.60 & 0.12 & 1.2 \\
\hline $699-74$ & -48 & - & 300 & 63 & 21 & $120+$ & $22+$ & 350 \\
\hline $699-74$ & -60 & - & 300 & 24 & 8 & $24+$ & $4.8+$ & 200 \\
\hline $699-77$ & -36 & - & 300 & 131 & 44 & $150+$ & $30+$ & 230 \\
\hline $699-77$ & -54 & - & 300 & 73 & 24 & $130+$ & $26+$ & 360 \\
\hline $699-78$ & -62 & - & 300 & 93 & 31 & $170+$ & $35+$ & 380 \\
\hline $699-80$ & $-43 c$ & - & 300 & 40 & 13 & $50+$ & $9.8+$ & 250 \\
\hline $699-81$ & -58 & - & 300 & 120 & 40 & $180+$ & $36+$ & 300 \\
\hline $699-83$ & -47 & - & 300 & 117 & 39 & $75+$ & $15+$ & 130 \\
\hline $699-84$ & $-35 A$ & 350 & - & 350 & 100 & 40 & 8 & 23 \\
\hline $699-86$ & -60 & 417 & - & 417 & 100 & 370 & 75 & 180 \\
\hline $699-89$ & -35 & - & 300 & 65 & 22 & $120+$ & $23+$ & 350 \\
\hline $699-96$ & -49 & - & 300 & 65 & 22 & $37+$ & $7.3+$ & 110 \\
\hline $699-97$ & -43 & - & 300 & 60 & 20 & $3.5 t$ & 0.65 & 11 \\
\hline $\operatorname{Han}-6$ & & - & 200 & 39 & 20 & $20+$ & $4.0+$ & 100 \\
\hline $\operatorname{Han}-9$ & & - & 200 & 72 & 36 & $20+$ & 4. $0+$ & 56 \\
\hline Han-19 & & - & 200 & 34 & 17 & $66+$ & $13+$ & 380 \\
\hline
\end{tabular}


To obtain a relation between the relative number $\mathrm{N} 2$ and transmissivity determined by pumping tests the following procedure was followed:

1. A table (Table VII) was prepared listing the measured transmissivities at wells for which number (N2) had also been determined.

2. For each well the number (N3) where $N 3$ is the equivalent of $\mathrm{N} 2$ for the interval screened or perforated during the test was obtained and entered in the table as were the numbers for the entire saturated thickness penetrated (N2).

3. The number (N3) was plotted versus the measured transmissivity obtained from the pumping test. Figure 3 shows that a distinct relationship exists between the measured transmissivity and the relative number for the screened or perforated interval (N3).

4. To estimate the transmissivity of the entire saturated thickness penetrated by the well we used the relationship reflected by the line shown on Figure 3 to conservatively estimate the transmissivity (T) from the number (N2). These estimates are given in Plate 3 .

We estimated the average hydraulic conductivity $(\bar{K})$ given in Table VI and Plate 4 by dividing the estimated transmissivity by the saturated interval penetrated by the well. 


\section{TABLE VII}

COMPARISON OF RELATIVE NUMBERS N2 AND N3

AND MEASURED TRANSMISSIVITY

N2 is based on entire well.

N3 is based on screened interval.

\begin{tabular}{|c|c|c|c|c|c|c|c|c|c|c|}
\hline & & Tran & issivi & & & e: & ative & Numbe & ers & \\
\hline Well & No. & Source & $f t^{2}$ & & & $\mathrm{~N}$ & & & N3 & \\
\hline $199-\mathrm{H} 4$ & -2 & 1 & 3 & & 3.7 & $\mathrm{x}$ & $10^{4}$ & & 15 & \\
\hline 299-WII & $l-2$ & 1 & 104 & & 8.7 & $x$ & $10^{4}$ & & 26 & \\
\hline $699-S 18$ & $3-E 12$ & 1 & 2 & & 1.3 & $x$ & $10^{5}$ & & 7 & \\
\hline $699-S 12$ & $2-3$ & $\begin{array}{l}1 \\
2,4\end{array}$ & $\begin{array}{l}350 \\
280\end{array}$ & & 5.2 & $\mathrm{x}$ & $10^{4+}$ & 40 & 00 & \\
\hline $699-56$ & $-\mathrm{E} 4 \mathrm{C}$ & 1 & $1.9 \times$ & $10^{3}$ & 1.4 & $\mathrm{x}$ & $10^{4}$ & & - & \\
\hline $699-1$ & -18 & 2,4 & $1.0 x$ & $10^{4}$ & 9.8 & $\mathbf{x}$ & $10^{4}$ & 8.1 & $x$ & $10^{4}$ \\
\hline $699-8$ & -17 & $\begin{array}{l}1 \\
2 \\
4\end{array}$ & $\begin{array}{l}3.5 \times \\
1.0 \times \\
1.0 \times\end{array}$ & $\begin{array}{l}10^{4} \\
10^{5} \\
10^{4}\end{array}$ & 5.7 & $\mathrm{x}$ & $10^{4}$ & 3.1 & $x$ & $10^{3}$ \\
\hline $699-10$ & $-E 12$ & 1 & 210 & & 2.1 & $x$ & $10^{5+}$ & 1.5 & $x$ & $10^{3}$ \\
\hline $699-14$ & -38 & 1 & 424 & & 7.2 & $x$ & $10^{4}$ & & - & \\
\hline $699-15$ & -26 & 2 & $3.1 \mathrm{x}$ & $10^{4}$ & 7.8 & $x$ & $10^{5}$ & 7.5 & $x$ & $10^{4}$ \\
\hline $699-17$ & -5 & $\begin{array}{l}2 \\
4\end{array}$ & $\begin{array}{r}750 \\
1.1 \times\end{array}$ & $10^{3}$ & 2.8 & $x$ & $10^{4}$ & & 600 & \\
\hline $699-20$ & $-\mathrm{E} 5 \mathrm{P}$ & 1 & 430 & & 1.2 & $x$ & $10^{6}$, & & - & \\
\hline $699-20$ & -20 & $\begin{array}{l}2 \\
4\end{array}$ & $\begin{array}{l}3.0 \mathrm{x} \\
3.2 \mathrm{x}\end{array}$ & $\begin{array}{l}10^{4} \\
10^{4}\end{array}$ & 1.6 & $\mathrm{x}$ & $10^{5}$ & 6.5 & $x$ & $10^{4}$ \\
\hline $699-20$ & -39 & 1 & 8 & & 9.8 & $x$ & $10^{4}$ & & 100 & \\
\hline $699-24$ & $-1 P$ & 1 & 90 & & 6.5 & $x$ & 10.4 & & 100 & \\
\hline $699-24$ & -33 & $\begin{array}{l}2 \\
4\end{array}$ & $\begin{array}{l}4.5 \times \\
3.9 \times\end{array}$ & $\begin{array}{l}10^{5} \\
10^{5}\end{array}$ & 3.4 & $\mathbf{x}$ & $10^{4}$ & 6 & $\mathbf{x}$ & $10^{4}$ \\
\hline $699-26$ & -15 & $\begin{array}{l}1 \\
2 \\
4\end{array}$ & $\begin{array}{l}9.5 x \\
9.3 \times \\
8.9 x\end{array}$ & $\begin{array}{l}10^{3} \\
10^{3} \\
10^{3}\end{array}$ & 2.0 & $x$ & $10^{5}$ & 4.3 & $x$ & $10^{4}$ \\
\hline $699-26$ & -89 & 1 & 530 & & 6.6 & $x$ & $10^{5}$ & 5.5 & $x$ & $10^{5}$ \\
\hline $699-31$ & $-53 B$ & $\begin{array}{l}1 \\
2,4\end{array}$ & $\begin{array}{l}2.1 \mathrm{x} \\
1.4 \mathrm{x}\end{array}$ & $\begin{array}{l}10^{4} \\
10^{4}\end{array}$ & 8.9 & $x$ & $10^{4}$ & 8.2 & $x$ & $10^{4}$ \\
\hline
\end{tabular}




\section{TABLE VII (continued)}

\begin{tabular}{|c|c|c|c|c|c|c|c|c|c|c|}
\hline \multirow{3}{*}{$\frac{\text { we } 11}{699-33}$} & \multirow{3}{*}{$\begin{array}{l}\text { No. } \\
-56\end{array}$} & \multicolumn{4}{|c|}{ Transmissivity } & \multirow{2}{*}{\multicolumn{3}{|c|}{$\frac{\text { Relative }}{\mathrm{N} 2}$}} & \multirow{2}{*}{\multicolumn{2}{|c|}{$\frac{\text { Numbers }}{\text { N } 3}$}} \\
\hline & & \multirow{2}{*}{$\begin{array}{l}\text { Source } \\
1 \\
2,4\end{array}$} & \multicolumn{3}{|c|}{$\mathrm{ft}^{2} / \mathrm{d}$} & & & & & \\
\hline & & & $\begin{array}{l}2.2 \\
2.1\end{array}$ & $\begin{array}{l}x \\
x\end{array}$ & $\begin{array}{l}10^{4} \\
10^{4}\end{array}$ & 1.3 & $\mathbf{x}$ & $10^{5}$ & $1.1 \mathrm{x}$ & $10^{5}$ \\
\hline $699-35$ & -9 & $\begin{array}{l}1 \\
2 \\
4\end{array}$ & $\begin{array}{l}2.3 \\
6.3 \\
7.2\end{array}$ & $\begin{array}{l}\mathrm{x} \\
\mathrm{x} \\
\mathrm{x}\end{array}$ & $\begin{array}{l}10^{3} \\
10^{3} \\
10^{3}\end{array}$ & 1.2 & $\mathbf{x}$ & $10^{4+}$ & $2.0 \times$ & $10^{3}$ \\
\hline $699-36$ & $-6 I A$ & 1 & 2.8 & $\mathrm{x}$ & $10^{3}$ & 5.4 & $\mathbf{x}$ & $10^{3}$ & $3.1 \mathrm{x}$ & $60^{3}$ \\
\hline $699-40$ & -33 & $\begin{array}{l}2 \\
4\end{array}$ & $\begin{array}{l}29 \\
21\end{array}$ & $\begin{array}{l}0 \\
0\end{array}$ & & 3.0 & $\mathbf{x}$ & $10^{5}$ & 40 & 0 \\
\hline $699-42$ & -12 & $\begin{array}{l}2 \\
4\end{array}$ & $\begin{array}{l}6.0 \\
8.6\end{array}$ & $\begin{array}{l}x \\
x\end{array}$ & $\begin{array}{l}10^{4} \\
10^{4}\end{array}$ & 6.3 & $\mathrm{x}$ & $10^{4}$ & $6.3 \times$ & $10^{4}$ \\
\hline $699-47$ & -35 & 2,4 & 40 & & & 2.0 & $\mathbf{x}$ & $10^{5}$ & $2.0 \times$ & $10^{5}$ \\
\hline $699-47$ & -60 & 1 & 3.3 & $\mathbf{x}$ & $10^{3}$ & 1.3 & $\mathbf{x}$ & $10^{4}$ & $1.2 \mathrm{x}$ & $10^{4}$ \\
\hline $699-55$ & $-50 A$ & $2,3,4$ & 4.0 & $\mathbf{x}$ & $10^{5}$ & 2.8 & $\mathbf{x}$ & $10^{5}$ & $2.1 \times$ & $10^{5}$ \\
\hline $699-61$ & -66 & $\begin{array}{l}1 \\
2\end{array}$ & $\begin{array}{l}4.0 \\
5.1\end{array}$ & $\begin{array}{l}\mathrm{x} \\
\mathrm{x}\end{array}$ & $\begin{array}{l}10^{4} \\
10^{4}\end{array}$ & 5.6 & $\mathbf{x}$ & $10^{5}$ & $2.0 \times$ & $10^{5}$ \\
\hline $699-62$ & $-43 F$ & $\begin{array}{l}2 \\
3,4 \\
5\end{array}$ & $\begin{array}{l}5.0 \\
5.1 \\
1.9\end{array}$ & $\begin{array}{l}\mathbf{x} \\
\mathbf{x} \\
\mathbf{x}\end{array}$ & $\begin{array}{l}10^{4} \\
10^{4} \\
10^{5}\end{array}$ & 2.8 & $x$ & $10^{5}$ & $2.0 x$ & $10^{5}$ \\
\hline $699-65$ & -50 & 2,4 & 6.4 & $\mathbf{x}$ & $10^{4}$ & 7.4 & $x$ & $10^{5}$ & $2.5 \mathrm{x}$ & $10^{5}$ \\
\hline $699-70$ & -68 & 4 & 3.2 & $\mathbf{x}$ & $10^{4}$ & 3.4 & $x$ & $10^{4+}$ & $3.4 \mathrm{x}$ & $=10^{4+}$ \\
\hline $699-71$ & -52 & 2,4 & 4.0 & $\mathrm{x}$ & $10^{3}$ & 3.7 & $x$ & $10^{3+}$ & $2.9 \times$ & $610^{3}$ \\
\hline $699-77$ & -54 & $\begin{array}{l}1 \\
2,4\end{array}$ & $\begin{array}{l}7.0 \\
4.3\end{array}$ & $\begin{array}{l}\mathbf{x} \\
\mathbf{x}\end{array}$ & $\begin{array}{l}10^{3} \\
10^{4}\end{array}$ & 1.3 & $\mathrm{x}$ & $10^{5+}$ & $4.0 \times$ & $10^{3}$ \\
\hline $699-84$ & $-35 A$ & 1 & & 4 & & 4.0 & $\mathrm{x}$ & $10^{4}$ & 25 & \\
\hline $\begin{array}{l}1-\mathrm{De} \\
2-\mathrm{Ki} \\
3-\mathrm{Bi} \\
4-\mathrm{Bi} \\
5-\mathrm{HO}\end{array}$ & $\begin{array}{l}\text { ju } 197 \\
\text { pp and } \\
\text { erscher } \\
\text { erscher } \\
\text { nstead }\end{array}$ & $\begin{array}{l}\text { Mudd } 197 \\
k \text { l } 1357, \\
k 1959, \\
\text { et al. I }\end{array}$ & & & & & & & & \\
\hline
\end{tabular}




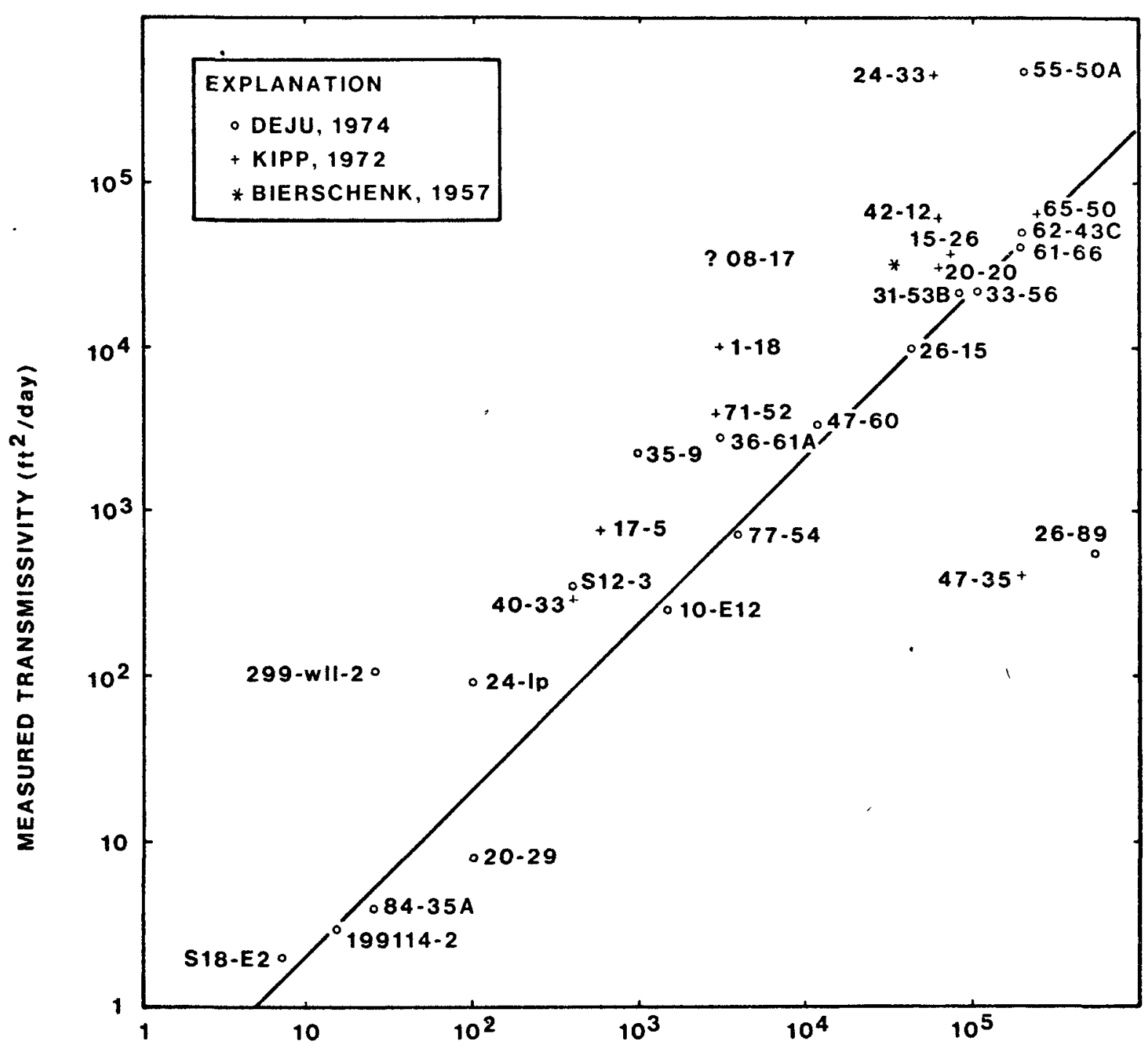

RELATIVE NUMBER OF SCREENED OR PERFORATED INTERVAL

FIGURE 3

RELATION BETWEEN MEASURED TRANSMISSIVITY AND N3 
CA-168-RAD -5

On Plate 4 we included for each data point the approximate percentage of the saturated sedimentary rocks sampled by each well. The following example illustrates the reason for this practice. Consider a point on the map where the thickness consists of $10^{\prime}$ of Pasco gravels with a hydraulic conductivity of $10,000 \mathrm{ft} / \mathrm{d}$ and $90^{\prime}$ of lower Ringold Formation with hydraulic conductivity of $10 \mathrm{ft} / \mathrm{d}$. The transmissivity is

$$
T=[10 \times 10,000+90 \times 10] \mathrm{ft}^{2} / \mathrm{day}=100,900 \mathrm{ft}^{2} / \mathrm{day},
$$

and the average hydraulic conductivity is

$$
K=T / b=\frac{100,900}{100} \text { or } 1009 \mathrm{ft} / \mathrm{d}
$$

The Pasco Gravels control the transmissivity. So, if a pumping test is conducted in a well that penetrated only the gravels measures the transmissivity of the Pasco Gravels, it also measures the transmissivity of the entire thickness to a first approximation. However the average hydraulic conductivity of the saturated section is 10 times less than the hydraulic conductivity of the Pasco gravels.

Plates 5 and 6 are cross-sections through the Reservation. These cross-sections represent intersecting vertical slices onto which nearby reference wells were projected. The land surface, water table, and basalt surface were taken from maps of these features. These cross-sections were constructed using existing driller logs. In these logs we recognized three intervals illustrated on the plates: the unsaturated zone, (2) the upper dominantly coarseclastic part of the zone of saturation, and (3) the lower dominantly fine-clastic part of the zone of saturation. The unsaturated zone contains both fine and coarse 
clastics and if the water table were to rise another 50', this simple three-part subdivision would be inappropriate. Fortunately the zone of saturation that we must deal with divides conveniently into the upper, coarse-grained part and the lower, fine-grained parts. The upper part consists of the Pasco Gravels and the Middle Ringold Conglomerate. In some places only one of the conglomerates was eroded away and the entire interval is composed of pasco Gravels. In other places the Pasco Gravels are above the water table.

By reporting both $T$ and $\bar{K}$, the cross-sections show where relatively small thicknesses of material with large hydraulic conductivities have a pronounced influence on $T$, whereas $\bar{K}$ increases only slightly. In general the largest $T$ and $K$ values $\left(100,000 \mathrm{ft}^{2} / \mathrm{d}\right.$ and $\left.500 \mathrm{ft} / \mathrm{d}\right)$ occur where the saturated thickness of the Pasco Gravels is largest. Intermediate values $\left(10,000 \mathrm{ft}^{2} / \mathrm{d}\right.$ and $\left.100 \mathrm{ft} / \mathrm{d}\right)$ occur where the Pasco Gravels are relatively thin or absent and the Middle Ringold Conglomerates are thick. Lower values $\left(1,000 \mathrm{ft}^{2} / \mathrm{d}\right.$ and $10 \mathrm{ft} / \mathrm{d}$ ) occur when the Middle Ringold Conglomerate is thin. The minimum values (100 $\mathrm{ft}^{2} / \mathrm{d}$ and $\left.\mathrm{l} \mathrm{ft} / \mathrm{d}\right)$ occur where only the lower fine-grained part (Lower Ringold Formation) of the zone of saturation is present or where the saturated thickness thins to zero.

\section{CONCLUSIONS}

The sedimentary rocks of the Pasco Basin include glaciofluviatile deposits and the Ringold Formation. They may also include sedimentary rorks interbedded with the basalts. In terms of the ground-water flow continuum these rocks are divided into the unsaturated zone, the upper dominantly coarse-clastic part of the zone of saturation and the lower dominantly fine-grained part of the zone of saturation. 
The effective porosity of the glaciofluviatile deposits that make up the upper coarse-clastic zone is no more 3 or $4 \%$. The effective porosity of the Ringold coarse clastics and fine clastics of the lower part has not been adequately measured--but is undoubtedly smaller.

Drillers' logs combined with pumping tests were used as shown on this report to estimate and map the transmissivity and mean hydraulic conductivity of the saturated sedimentary rocks. They show that the largest values of transmissivity and mean hydraulic conductivity in the unconfined aquifer occur where the saturated thickness of the Pasco Gravels is largest. Intermediate values occur where the Pasco Gravels are thinnest and the Middle Ringold Conglomerates are thick. Low values occur where the Middle Ringold Conglomerate is thin, the Pasco Gravels are non-existent, and the Lower Ringold makes up the bulk of the saturated section.

\section{REFERENCES}

1. Environmental Statement of Waste Management Operations, Hanford Reservation, WASH-1538, U. S. Energy Research and Development Administration, Richland, Washington (1975).

2. W. H. Bierschenk, Hydraulic Characteristics of Hanford Aquifers, HW-48916, General Electric Company, Richland, Washington, $38 \mathrm{pp}$. (1957).

3. W. H. Bierschenk, Aquifer Characteristics and GroundWater Movement at Hanford, HW-60601, General Electric Company, 81 pp. (1959). 
4. R. A. Deju, The Hanford Field Testing Program,

R. A. Deju and Associates Report to Atlantic Richfield Hanford Company under AEC Contract AT(45-1)-2130, $145 \mathrm{pp}$. (1974).

5. J. F. Honstead, M. W. McConiga, and J. R. Raymond, Gable Mountain Ground Water Tests, HW-34532, General Electric Company, 23 pp. (1955).

6. K. L. Kipp and R. D. Mudd, Collection and Analysis of Pump Test Data for Transmissivity Values, BNWL-1709, Battelle Pacific Northwest Laboratories, Richland, Washington, $63 \mathrm{pp}$. (1973).

7. R. C. Newcomb, J. R. Strand, and F. J. Frank, Geology and Ground-Water Characteristics of the Hanford Reservation of the U. S. Atomic Energy Commission, Washington, U. S. Geol. Surv., Prof. Paper 717, 78 pp. (1972).

8. W. K. Summers and R. A. Deju, A Preliminary Review of the Regional Hydrology of the Hanford Reservation, R. A. Deju and Associates Report to ARHCO under AEC Contract AT (45-1)-3140, 54 pp. (1974).

9. Subsurface Investigation and Foundation Engineering Evaluation, Shannon and Wilson, Inc., Washington Public Power Supply System Nuclear Project No. 1, Seattle, Washington (1973).

10. J. W. Crosby, III, J. V. Anderson, R. L. Fenton, J. P. Kiesler, B. A. Siems, Borehold Geophysical Investigation of the Area Surrounding the Hanford Atomic Energy Works, Final Report to US AEC, Washington State University College of Engineering, Research Division, Research Report 72/11-71 (1971). 
11. J. W. Crosby, III, J. V. Anderson, R. I. Fenton, and B. A. Siems, Geophysical Borehole Investigation of Test Holes $B-12, B-35$, and $B-26$, WSU College of Engineering, Research Division, Research Report No. 72/11-121 (1972).

12. J. W. Crosby, III, B. A. Siems, J.W. Anderson, and T. I. Weber, Final Report Geophysical Borehole Investigation of the WPPSS Nuclear Project No. I Site, WSU College of Engineering, Research Division, Research Report No. 73/11-19 (1973).

13. J. W. Crosby, III, J. V. Anderson, G. B. Lane, and T. L. Weber, Geophysical Borehole Investigations of the WPPSS WNP-1 and WNP-4 Site, WSU College of Engineering, Research Division, Research Report No. 74/15-54 (1974).

14. J. R. McHenry, Properties of Soizs of the Hanford Project, HW-53218, General Electric Company, 63 pp. (1957).

15. K. L. Kipp and R. D. Mudd, Selected Water Table Contour Maps and Wezz Hydrographs for the Hanford Reservation, 1944-1973, BNWL-B-360, Battelle Pacific Northwest Laboratories, $639 \mathrm{pp}$. (1974).

16. R. E. Brown and J. E. Raymond, Geophysical Seismic Evaluation Study at Hanford, BNWL-47, Battelle Pacific Northwest Laboratories, 43 pp. (1964).

17. D. J. Brown, Subsurface Geology of the Hanford Separation Areas, HW-61780, General Electric Company (1959).

18. D. J. Brown, An Eolian Deposit Beneath 200 West Area, HW-67549, General Electric Company, 18 pp. (1960).

19. D. J. Brown and W. P. Haney, The Role of Geology in the Disposal of Radioactive Wastes, BNWL-SA-57, Battelle Pacific Northwest Laboratories, 18 pp. (1965). 
20. R. E. Brown, The Surface of the Ringold Formation Beneath the Hanford Works Area, HW-65230, General Electric Company, 13 pp. (1960a).

21. R. E. Brown, An Introduction to the Surface of the Ringold Formation Beneath the Hanford Works Area, HW-66289, General Electric Company, 11 pp. (1260b).

22. R. E. Brown and M. W. McConiga, "Some Contributions to the Stratigraphy and Indicated Deformation of the Ringold Formation," Northwest Science, Vol. 34, No. 2, pp. 43-54 (1960).

23. R. E. Brown and D. J. Brown, The Ringold Formation and Its Relationship to other Formations, HWSA2319, General Electric Company, 17 pp. (1961).

24. R. C. Newcomb, "Ringold Formation of Pleitocene Age in Type Locality, the White Bluffs, Washington," Am. Jour. Sci., Vol. 256, pp. 328480 (1958).

25. R. C. Newcomb, "Age of the Palouse Formation in the Walla Walla and Umatilla River Basins, Oregon and Washington," Northwest Science, Vol. 35, No. 4, pp. 122127 (1961).

26. D. J. Brown and P. O. Rowe, 200-N Area Aquifer Evaluation, HW-67326, General Electric Company, 14 pp. (1960).

27. D. D. Tillson, D. J. Brown, and J. R. Raymond, River Water-Ground Water Relationships Along a Section of the Columbia River Valley, paper prepired for oral presentation and publication in the proceedings of American Society of Civil Engineers Meeting on Water Resource Engineering held in New Orleans, Lousiana, February 3-7, 1969 (1968). 


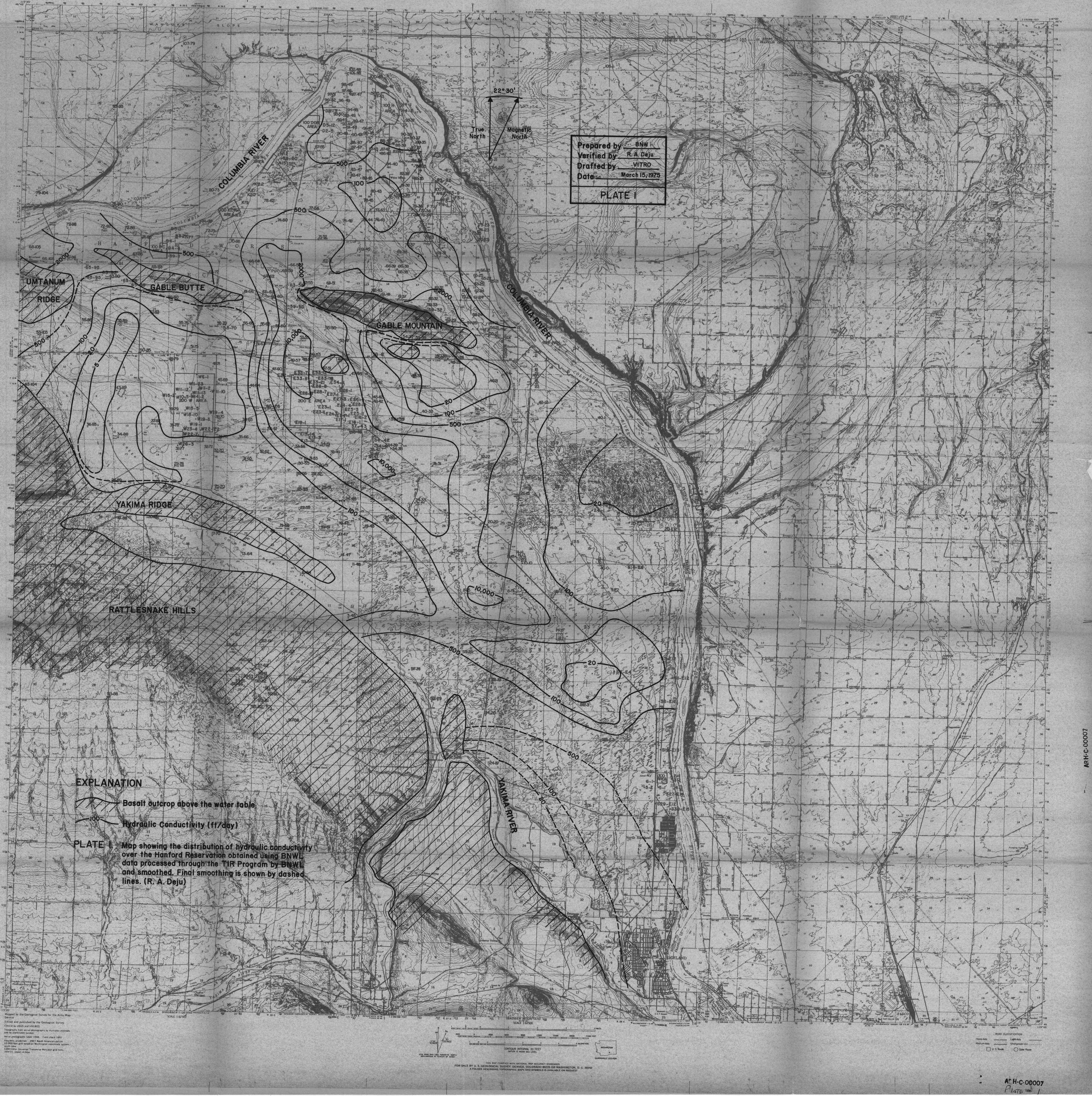




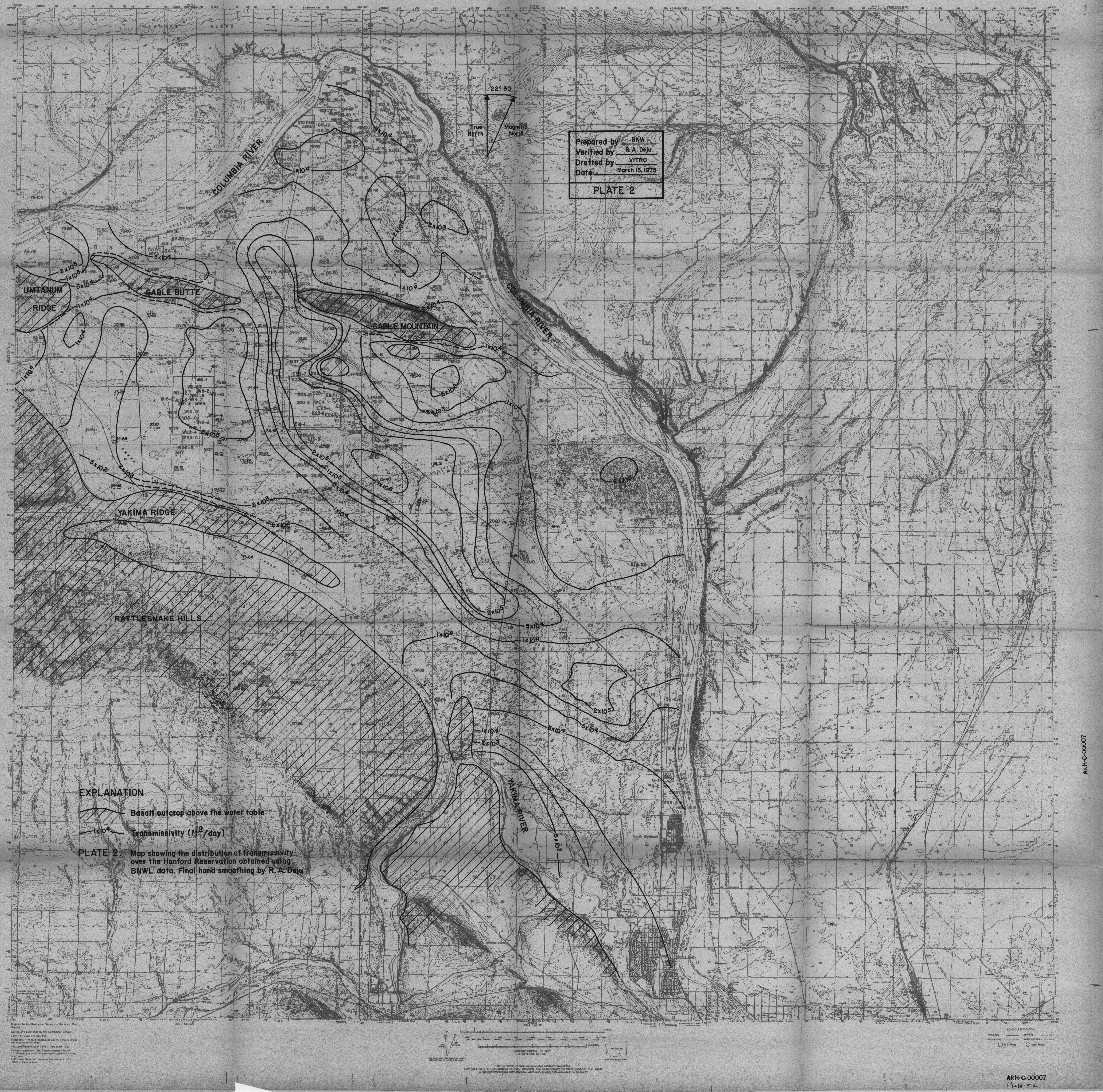




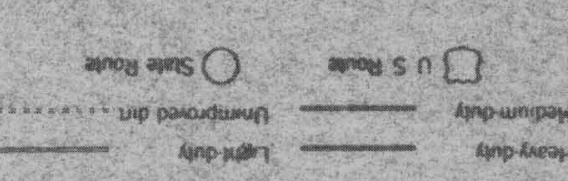

$+1=2+2$
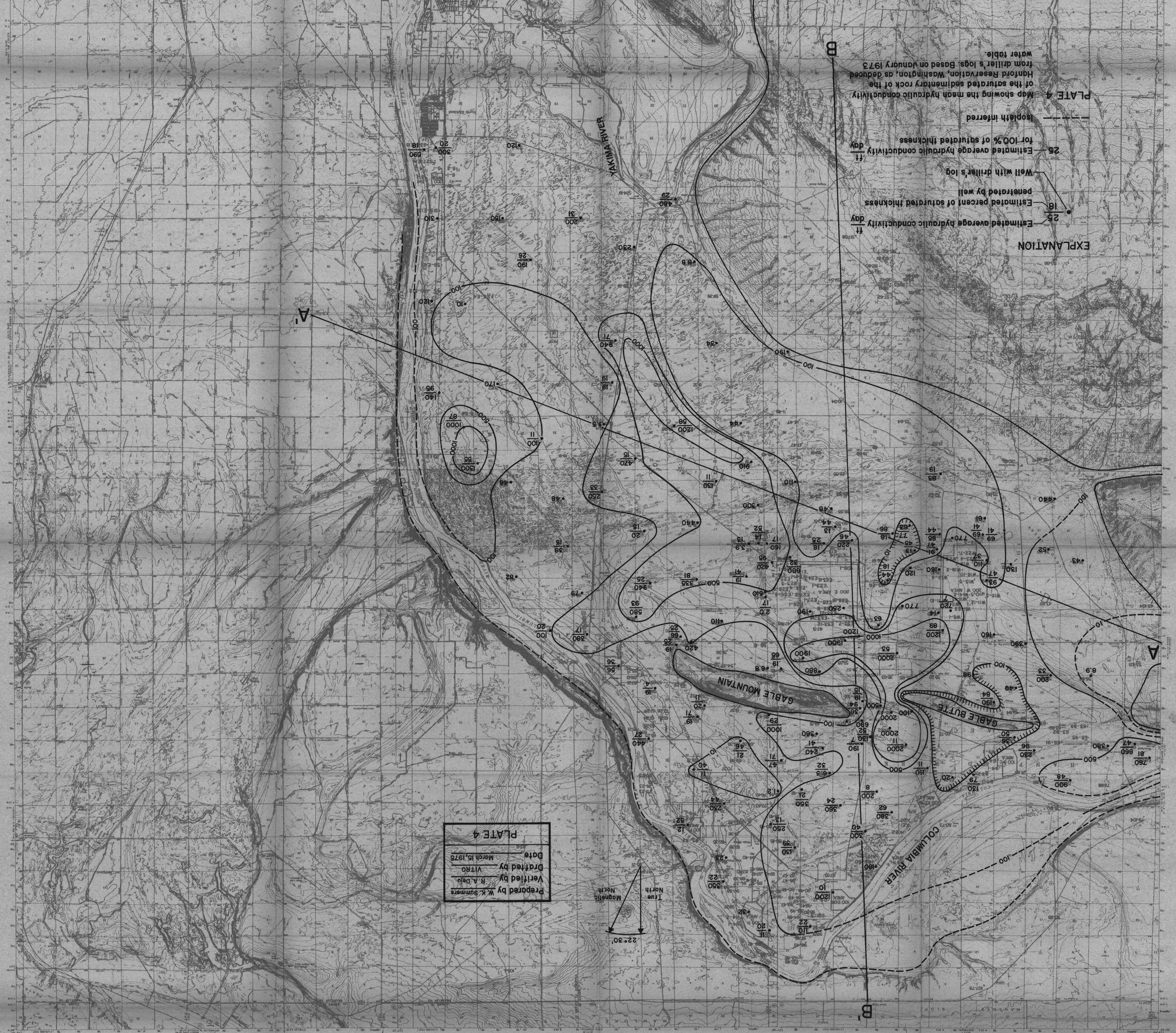



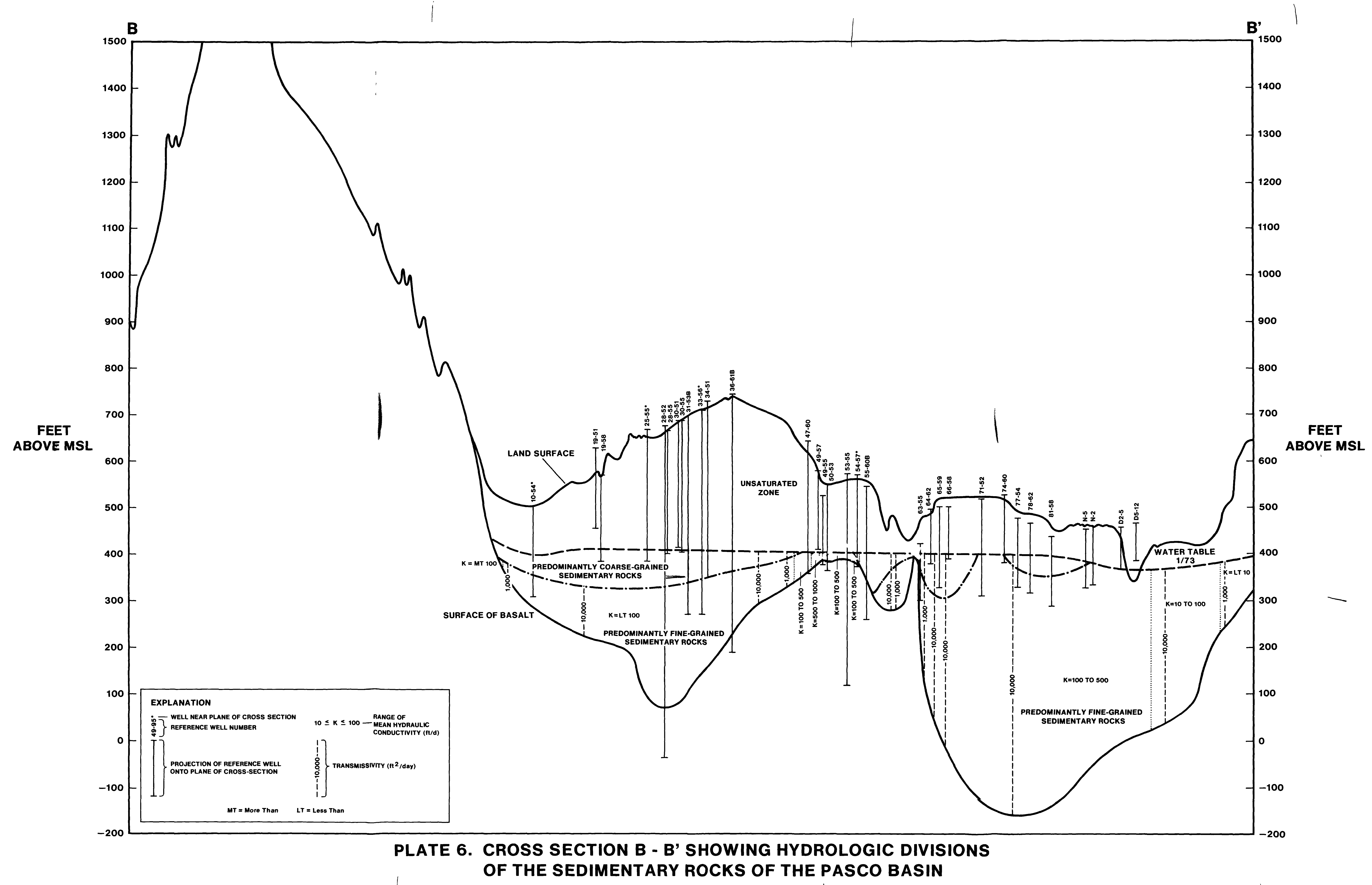

